\title{
Banco Mundial: dos bastidores aos 50 anos de Bretton Woods (1942-1994)
}

João Márcio Mendes Pereira*

\section{RESUMO}

O artigo examina a história do Banco Mundial desde as primeiras negociaçóes entre Estados Unidos e Grá-Bretanha para o desenho da nova ordem econômica mundial no pós-guerra até o seu aniversário de 50 anos. Argumenta-se que, apesar da fachada técnica, o Banco sempre atuou, ainda que de diferentes formas, na interface dos campos político, econômico e intelectual em nível internacional, em funçáo da sua condição singular de emprestador, ator político e veiculador de ideias e prescriçôes sobre o que fazer em matéria de desenvolvimento capitalista, em clave anglo-saxônica. Nesse sentido, desde o início o banco utilizou o crédito como alavanca para ampliar a sua influência e institucionalizar ideias econômicas, concepçôes de mundo e prescriçóes políticas nos Estados-cliente. Com base em ampla e variada literatura internacional e fontes da própria instituição, o trabalho aborda o tema levando em consideração, de forma articulada, a economia política na qual a instituiçấo operou e o seu funcionamento como burocracia complexa.

Palavras-chave: Banco Mundial; Bretton Woods; Estados Unidos; multilateralismo; desenvolvimento.

\section{ABSTRACT}

The article examines the history of the World Bank from the first negotiations between the United States and Great Britain for the design of a new post-war economic world order until his 50th anniversary. It argues that, despite the technical forefront and in different forms, the Bank has always worked at the interface of international political, economic and intellectual fields, due to its singular condition as lender, political actor and disseminator of ideas and prescriptions on capitalist development in an Anglo-Saxon clef. Accordingly, 
from the outset, the Bank used credit as leverage to extend its influence and institutionalize economic ideas, worldviews and policy prescriptions in client states. Based on extensive and diverse international literature, and on World Bank's own sources, the article addresses the issue taking into account, in an articulated manner, the political economy in which the institution operated and its functioning as a complex bureaucracy.

Keywords: World Bank, Bretton Woods, United States, multilateralism, development.

O Banco e seus funcionários não deverão intervir em assuntos políticos de nenhum membro; nem serão influenciados em suas decisóes pelo caráter político do membro ou dos membros em questão. Somente considerações econômicas deverão ser relevantes para as suas decisóes, e estas devem ser ponderadas de forma imparcial.

Banco Internacional para Reconstrução

e Desenvolvimento Artigos de Fundação, 1944

Bom conselho é raro e bom conselho que é ouvido é mesmo excepcional. Mas o banco fornece um poderoso amplificador - a possibilidade de assistência para financiar as suas recomendaçóes.

Edward Mason e Robert Asher The World Bank since Bretton Woods, 1973

Em geral, as políticas e os programas do Grupo Banco Mundial têm sido consistentes com os interesses norteamericanos. Isto é particularmente verdadeiro em questôes de alocação geral ao país e temas políticos sensíveis. O caráter internacional do Banco Mundial, sua estrutura corporativa, a solidez da sua equipe administrativa e a pesada estrutura de voto do banco 
asseguram a consistência ampla entre suas políticas e práticas e os objetivos econômicos e políticos de longo prazo dos Estados Unidos.

U.S. Department of Treasury United States Participation in the Multilateral Development Banks in the 1980s, 1982

No ano de 2014 o Banco Mundial completa 70 anos, encontrando-se em plena capacidade de operação, malgrado as críticas e pressóes à esquerda e à direita das quais tem sido alvo. Para contribuir com o esforço de avaliação global da história dessa instituição, este artigo analisa os seus primeiros cinquenta anos de atuação, traçando um panorama e um balanço das principais tomadas de posiçáo em sua trajetória sinuosa, mas ascendente, de poder.

A pesquisa acadêmica no Brasil sobre o tema ainda é escassa, apesar de o país figurar historicamente entre os cinco maiores clientes do banco e de a América Latina ser a principal região de operações da instituição. Já a literatura internacional é vasta, mas profundamente heterogênea. Sem pretensôes de exaustividade, cabe um breve comentário a esse respeito. Parte muito significativa da produção intelectual é dominada por economistas e tende a enfatizar a atuação financeira da entidade, o que é fundamental, mas com frequência menospreza ou mesmo desconsidera outras dimensóes relevantes. Por outro lado, grande parte dos estudos se limita a abordar a atuaçáo do banco sob o prisma setorial (infraestrutura, educação, saúde, política econômica etc.), deixando de lado a articulação intersetorial das suas açôes e a história mais geral da entidade. Em outro recorte é possível distinguir os trabalhos que abordam a instituição a partir da política externa dos principais Estados-membros, esvaziando a análise da organização burocrática e seus condicionantes, daqueles que tratam o banco como uma burocracia complexa, a partir da Sociologia das Organizaçóes, desconsiderando a relaçáo da entidade com as disputas no sistema interestatal. Por sua vez, em outra chave de leitura, podem-se diferenciar os estudos que se encerram numa perspectiva disciplinar - amplíssima maioria - e aqueles que adotam uma abordagem global e transdisciplinar. Por fim, mas não menos importante, é digno de nota que uma parcela considerável da literatura é fortemente normativa, a favor ou contra a atuação da instituição, com pouco distanciamento crítico em relação ao objeto, ainda que, com frequência, sob a aparência de análises estritamente técnicas.

A abordagem aqui adotada difere de parte significativa da literatura. $\mathrm{O}$ argumento central é o de que, malgrado a fachada técnica, o banco sempre atuou, ainda que de diferentes formas, na interface dos campos político, econômico e intelectual a nível internacional, 
em função da sua condição singular de emprestador, formulador de política e indutor de ideias e prescriçôes sobre o que fazer em matéria de desenvolvimento capitalista, em clave anglo-saxônica. Dessa perspectiva, o banco é abordado como um ator político, intelectual e financeiro.

Em termos teórico-metodológicos, a relação do banco com os governos nacionais não deve ser vista como mera imposição externa unilateral. É verdade que existem formas e mecanismos de pressão de diferentes tipos (financeiros, políticos, intelectuais e simbólicos) acionados pelo banco conforme o caso e as circunstâncias, mas isso é apenas uma parte da história. Com efeito, a atuação do banco se deu — e ainda se dá — em meio a uma malha crescente de relaçôes que envolve agentes nacionais e internacionais públicos, privados, não governamentais, filantrópicos e empresariais, os quais, com meios e níveis de gravitação distintos, apoiam, formulam, adaptam, negociam e veiculam as ideias e prescrições da instituição. A efetividade das açôes do Banco, portanto, foi e continua sendo dependente da construção de pontos de sustentação, negociação e difusão dentro e fora dos espaços nacionais.

Com base em fontes da própria instituição e em ampla e diversa literatura especializada, o trabalho analisa o "banco no mundo e o mundo do banco", buscando compreender, de forma articulada, a economia política na qual a instituiçáo operou e o seu funcionamento como burocracia complexa. O texto está organizado em sete seçóes. Inicialmente, remonta às primeiras negociaçôes entre Estados Unidos (EUA) e Grã-Bretanha para o desenho da nova ordem econômica mundial no pós-guerra, que desaguariam na conferência de Bretton Woods, em 1944, destacando o papel proeminente do governo americano. A seguir, analisa o perfil de atuação do banco até 1960, salientando a sua trajetória singular em relação à das demais organizaçóes multilaterais construídas no período. Após, discute as razões e as implicaçôes da criação, em 1960, da Associação Internacional de Desenvolvimento como braço auxiliar do banco. Na seção seguinte, apresenta e problematiza as continuidades e inovaçôes da atuação do banco entre 1963 e 1968. Na sequência, aborda as linhas centrais da gestáo de McNamara (1968-1981), durante a qual a instituiçáo alcançou novo patamar internacional. Após, aborda o início e a dinâmica das políticas de ajustamento estrutural, que deram o tom da conduta do banco durante os anos 1980. Por fim, analisa as principais açóes da instituição do fim da guerra fria até o seu cinquentenário, quando se condensaram inúmeras críticas e interrogações quanto ao futuro da entidade.

\section{Das primeiras negociações a Bretton Woods (1942-44)}

Em 1941, antes do ataque japonês à base naval de Pearl Harbor, o governo americano iniciou a elaboração de propostas para o desenho da nova arquitetura econômica internacional que deveria se plasmar após o fim da guerra. Impulsionado pelo aumento astronômico 
do PIB nacional durante o conflito, o objetivo de Washington era criar as condiçóes que assegurassem o livre comércio para os produtos do país, a abertura dos mercados estrangeiros ao capital americano e o acesso irrestrito a matérias-primas necessárias à sua pujança econômica, num mundo instável e largamente constituído por impérios.

O responsável pelo trabalho era Harry D. White, assessor-chefe do Tesouro. Em 1942, os EUA começaram a negociar informalmente com a Grä-Bretanha, pela qual respondia John Maynard Keynes, assessor principal do Tesouro britânico. Ambos consideravam indispensável a construção de um sistema de cooperação econômica baseado em regras e instituiçôes multilaterais que promovesse a estabilidade econômica, o pleno emprego, o livre comércio e o investimento internacional, vistos como condiçôes para a paz e a prosperidade entre as naçôes. ${ }^{1}$ Ambos também defendiam que os Estados protegessem suas economias contra pressôes financeiras internacionais. Essa abordagem configurava uma reação ao capitalismo liberal que marcara os anos pré-guerra. Com apoio significativo entre industriais, sindicatos de trabalhadores e políticos de orientação keynesiana, tal ideário enfrentava a oposição de banqueiros privados e administradores dos bancos centrais que haviam dominado as políticas financeiras antes de $1931 .^{2}$

Todavia, britânicos e americanos divergiam profundamente sobre o conteúdo e os instrumentos que deveriam assegurar a realização de tais princípios. Para os britânicos era fundamental assegurar a zona da libra como seu espaço exclusivo. Os americanos, por sua vez, pressionavam pela demolição de qualquer preferência inglesa no território do império britânico e buscavam abrir os mercados domésticos dos demais países. ${ }^{3}$

Keynes insistia em duas propostas. ${ }^{4}$ Primeira, a criação de um banco central internacional (a Uniāo Internacional de Compensaçôes) com poder para emitir uma nova moeda de reserva mundial (o bancor) em substituição ao ouro, mas a ele conversível, cuja funçáo seria a de assegurar o cumprimento de regras internacionais em matéria financeira, prover liquidez à economia e operar ajustes simétricos e automáticos entre países com déficit e superávit no balanço de pagamento. Segunda, a criação de um fundo, originalmente apenas

\footnotetext{
${ }^{1}$ EICHENGREEN, Barry. A globalização do capital: uma história do sistema monetário internacional. São Paulo: Editora 34, 2000. p. 127; GWIN, Catherine. U.S. relations with the World Bank, 1945-1992. In: KAPUR, Devesh et al. (Eds.). The World Bank: its First Half Century. Perspectives. Washington, DC: Brookings Institution Press, [S.d.]. v. 2, p. 196.

${ }^{2}$ HELLEINER, Eric. States and the Reemergence of Global Finance: from Bretton Woods to the 1990s. Ithaca: Cornell University Press, 1994. p. 49-50.

${ }^{3}$ PAULY, Louis. Who Elected the Bankers? Surveillance and Control in the World Economy. Ithaca: Cornell University Press, 1997. p. 82; LICHTENSZTEJN, Samuel; BAER, Mônica. Fundo Monetário Internacional e Banco Mundial: estratégias e políticas do poder financeiro. São Paulo: Brasiliense, 1987. p. 27-34; EICHENGREEN, Barry, op. cit., p. 138.

${ }^{4}$ BLOCK, Fred. Los orígenes del desorden económico internacional. México, DF: Fondo de Cultura Económica, 1989. p. 82; AGLIETTA, Michel; MOATTI, Sandra. El FMI: del orden monetario a los desórdenes financieros. Madri: Akal, 2002. p. 17-19; SANAHUJA, José. Altruismo, mercado y poder: el Banco Mundial y la lucha contra la pobreza. Barcelona: Intermón Oxfam, 2001. p. 48-50.
} 
para a reconstrução dos países atingidos pela guerra, mas depois ampliado para a promoção do desenvolvimento internacional, a ser financiado com recursos da União Internacional de Compensaçōes.

Quando começaram as negociaçóes formais em 1943, as propostas keynesianas foram rejeitadas pelos americanos. Assim, em lugar de um "banco central internacional”, acordou-se a criação de um fundo de estabilização monetária desprovido de mecanismos de ajuste globais em caso de superávit, como era o caso dos EUA, de modo que todo o peso dos ajustes recairia sobre países em situaçáo deficitária. ${ }^{5}$ Ao mesmo tempo, em lugar de um fundo, acordou-se a criação de um banco para "reconstruçáo e desenvolvimento". ${ }^{6}$

Se as propostas de White constituíram a base sobre a qual se deu a negociação assimétrica entre as duas potências, é importante lembrar que algumas delas sofreram veto do establishment americano e logo foram descartadas. Entre elas, por exemplo, a criação de uma moeda própria (a unitas), a realização de empréstimos a partir, exclusivamente, do seu próprio capital (e não de recursos tomados a partir da venda de títulos nos mercados financeiros privados), a missáo de ajudar a estabilizar os preços das matérias-primas e, mais importante, o fornecimento de empréstimos contracíclicos no caso de depressão da economia internacional. ${ }^{7}$ Tais propostas claramente projetavam a experiência do New Deal para o plano internacional, assentada no papel diretivo e regulador do Estado sobre a atividade econômica. Nesse sentido, rechaçavam o laissez-faire e se identificavam com as ideias de Keynes.

Depois de dois anos de negociaçôes reservadas entre EUA e Grã-Bretanha, o governo Roosevelt promoveu em julho de 1944 a Conferência Monetária e Financeira das Naçôes Unidas, na cidade de Bretton Woods, com a presença de 45 delegaçóes. Vale recordar que, num dos primeiros encontros privados com White, ainda em 1942, Keynes argumentara contra a realização de uma conferência e a favor de negociações restritas entre EUA e Grã-Bretanha. Derrotado, Keynes se manifestou, num informe posterior ao Tesouro britânico, expressamente contra a participação de países considerados menos desenvolvidos em Bretton Woods. Para a diplomacia americana, porém, era indispensável a realização de um encontro internacional que formalizasse um acordo multilateral amplo, dirigido pelos EUA. ${ }^{8} \mathrm{Na}$ abertura da conferência, Keynes reconheceu o fato de que o documento-base para a criação de um banco internacional se devia "antes de tudo à iniciativa e à capacidade do Tesouro dos Estados Unidos"?

\footnotetext{
${ }^{5}$ SANAHUJA, José A., op. cit., p. 51.

${ }^{6}$ GARDNER, Richard. La diplomacia del dólar y la esterlina. Barcelona: Galaxia Gutenberg/Círculo de Lectores, 1994. p. 168; KAPUR, Devesh et al. The World Bank: its First Half Century. History. Washington, DC: Brookings Institution Press, 1997. v. 1, p. 57.

${ }^{7}$ GARDNER, Richard, op. cit., p. 169-171; TOUSSAINT, Eric. Banco Mundial: el golpe de Estado permanente. Madri: El Viejo Topo, 2006. p. 29-30.

${ }^{8}$ KAPUR, Devesh et al., op. cit., 62.

9 Apud MASON, Edward; ASHER, Robert. The World Bank since Bretton Woods. Washington, DC: The Brookings Institution, 1973. p. 13.
} 
O resultado do encontro materializou a hegemonia americana na reorganização política e econômica internacional no pós-guerra. Produto de uma mudança drástica na estrutura de poder internacional, institucionalizou uma nova ordem monetária baseada no dólar. Ao mesmo tempo foram criados o Fundo Monetário Internacional (FMI) e o Banco Internacional para Reconstrução e Desenvolvimento (Bird), organizaçóes financeiras multilaterais de novo tipo, cuja ossatura institucional expressava e reproduzia a assimetria de poder configurada no sistema internacional. ${ }^{10}$ Por outro lado, as provisôes do acordo em favor do controle de capitais refletiram a vitória dos embedded liberals contra os banqueiros de Wall Street. ${ }^{11}$

A missão primordial do Bird consistia em fornecer garantias e empréstimos para a reconstrução dos países-membros afetados pela guerra. O desenvolvimento figurava lateralmente. Convencido de que os investidores privados poderiam não prover o fluxo líquido de dólares necessário à reconstrução, White concebeu um banco que garantisse títulos estrangeiros e, quando necessário, emprestasse diretamente para Estados. Objetivo: encorajar o capital privado ao investimento produtivo, mais do que efetuar empréstimos. ${ }^{12}$ De acordo com o seu estatuto, não cabia a ele competir com os bancos comerciais privados e muito menos fortalecer o setor público e quaisquer formas mistas de economia, mas sim financiar projetos para fins produtivos relacionados com obras públicas de fácil definição, supervisão e aferição de resultados que não fossem de interesse direto da banca privada. Ademais, cabia ao banco promover o investimento de capitais estrangeiros, por meio de garantias ou participação em empréstimos e outros investimentos realizados por particulares, desde que relacionados com planos específicos de reconstrução ou desenvolvimento.

O banco consagrou, em seus estatutos e orientaçóes operacionais, as visôes americanas sobre como a economia mundial deveria ser organizada. ${ }^{13}$ Isso incluía a decisão de que a instituição não emprestaria diretamente a empresas privadas. Incluía, também, a supervisão do banco por representantes nacionais, o que passava pela escolha de um assento permanente na sua diretoria executiva e pela definição do papel dos diretores executivos.

As decisôes sobre a localizaçáo do Bird e o papel dos diretores executivos provocaram efeitos duradouros sobre as suas operaçôes, facilitando a interação cotidiana com o governo americano. A Grá-Bretanha e muitos outros membros queriam que o banco fosse localizado fora dos EUA, para distanciá-lo da política americana..$^{14}$ Quando ficou claro que os EUA não aceitariam, propuseram instalá-lo em Nova York, o coração financeiro, e não em Washington, o centro político do país. Mas Roosevelt náo abria mão de Washington. Nas

${ }^{10}$ EICHENGREEN, Barry, op. cit.; TABB, William. Economic Governance in the Age of Globalization. Nova York: Columbia University Press, 2004; GOWAN, Peter. A roleta global: uma aposta faustiana de Washington para a dominação do mundo. Rio de Janeiro: Record, 2003.

${ }^{11}$ HELLEINER, Eric, op. cit., p. 50; BLOCK, Fred, op. cit., p. 89-90.

${ }^{12}$ GWIN, Catherine, op. cit., p. 197.

${ }^{13}$ GWIN, Catherine, op. cit., p. 198-200.

${ }^{14}$ BLOCK, Fred, op. cit., p. 116. 
palavras do Secretário do Tesouro, Henry Morgenthau, o objetivo era "trasladar o centro financeiro do mundo de Londres e Wall Street para o Departamento do Tesouro dos Estados Unidos, e criar uma nova mentalidade entre as naçôes a respeito das finanças internacionais", por meio de instituiçốes concebidas como "instrumentos de governos soberanos e não de interesses financeiros privados". ${ }^{15}$

Essa mesma perspectiva moldou a posição americana sobre o papel dos diretores-executivos do banco. No debate sobre as funçôes dos mesmos, a Grã-Bretanha procurou minimizar a influência dos governos nacionais. Ela argumentava que os diretores deveriam residir em seus países natais e visitar o banco em intervalos regulares para tratar de assuntos importantes, deixando as questôes do dia a dia para a gerência e o staff, de perfil técnico e internacional. Em contraste, os EUA, que estavam subscrevendo a maior parte do capital do banco, insistiam que os diretores servissem em tempo integral e exercessem mais iniciativa e controle sobre operaçôes e política. A visão dos EUA prevaleceu.

Quando Roosevelt enviou ao Congresso os acordos de Bretton Woods para a aprovação em janeiro de 1945, teve que promover uma campanha ampla para ganhar apoio para as duas novas organizaçôes, em resposta à oposição de Wall Street e do Partido Republicano. ${ }^{16}$ Em comum, tais forças repudiavam a aceitaçáo de qualquer compromisso multilateral que implicasse cessão de parcelas da soberania ou restringisse a projeção global do poder político e econômico americano. Além disso, repeliam a criação de organizaçôes internacionais fortes, capazes de regular os capitais privados e, de algum modo, com eles competir, associando-as imediatamente a Roosevelt, ao New Deal e ao keynesianismo. ${ }^{17}$

O governo defendeu a participação dos EUA nas duas instituiçôes como condição para assegurar a estabilidade da economia internacional no pós-guerra e a revitalização dos mercados para os produtos industriais e agrícolas americanos. No final, a depuração das propostas originais de White antes mesmo da conferência, a natureza multilateral do Bird, o seu papel de garantidor (mais do que de financiador) e a primazia incontestável dos EUA nas novas instituiçôes, combinados à insistência do governo de que a manutenção da paz dependia da ratificação dos acordos pelos EUA, garantiram a aprovação dos acordos de Bretton Woods pelo Congresso em 1945 por ampla maioria.

\section{O início das operaçóes}

O início da guerra fria em março de 1947 alterou brusca e radicalmente a paisagem política mundial. Com base na Doutrina Truman, o governo americano passou a oferecer assis-

\footnotetext{
${ }^{15}$ Apud GARDNER, Richard, op. cit., p. 172.

${ }^{16}$ GARDNER, Richard, op. cit., p. 246.

${ }^{17}$ SANAHUJA, José, op. cit., p. 53; TOUSSAINT, Eric, op. cit., p. 31. 
tência política, econômica e militar aos "povos livres", i.e., a qualquer governo supostamente sob ameaça comunista interna ou externa. ${ }^{18}$ Para competir com a União Soviética (URSS) e administrar a economia mundial sob sua égide, os EUA constituíram parceiros subalternos fortes, mediante ajuda econômica farta a aliados estratégicos, como a Europa Ocidental, o Japão, o Canadá e a Austrália. O instrumento principal dessa política foi a ajuda bilateral, no bojo da qual se destacou o Plano Marshall. Na esteira dessa iniciativa, os EUA criaram uma ampla infraestrutura institucional de assistência externa financeira, militar, técnica e científica. ${ }^{19}$ Essa atuação foi fundamental para, em nome da liberdade e da democracia, disseminar instituiçóes americanas no exterior, administrar politicamente o mundo não comunista e conter o comunismo dentro das suas próprias fronteiras.

Ao mesmo tempo, o governo americano buscou instrumentalizar diretamente as instituiçóes financeiras multilaterais criadas em Bretton Woods conforme a sua política externa. O Bird - logo chamado de Banco Mundial a partir de meados dos anos 1950 — foi uma delas. Apequenado diante da magnitude financeira do Plano Marshall, a instituição acabou desempenhando papel menor na reconstrução. ${ }^{20}$ Mesmo assim, empréstimos para o "desenvolvimento" do entáo chamado Terceiro Mundo somente se tornariam o carro-chefe da sua atuação a partir do final dos anos 1950.

O banco concedia empréstimos de dois tipos: para programas e para projetos. No primeiro caso, as operaçôes eram de volume financeiro maior e tinham o objetivo, em geral, de financiar importaçóes ou aliviar desequilíbrios no balanço de pagamentos, sendo autorizadas em circunstâncias especiais para clientes considerados mais solventes e politicamente estratégicos para os EUA, como a Europa Ocidental e o Japão. No segundo caso, os empréstimos eram menores e se destinavam ao financiamento de projetos produtivos, autorizados para clientes considerados menos solventes - na maioria dos casos, países de renda média. ${ }^{21}$

A ênfase no financiamento de projetos "produtivos" se adequava ao veto preventivo dos bancos privados americanos à concorrência financeira que o Bird pudesse lhes fazer. ${ }^{22}$ Isso

\footnotetext{
${ }^{18}$ BANDEIRA, Luiz Alberto Moniz. Formação do império americano: da guerra contra a Espanha à guerra no Iraque. 2. ed. Rio de Janeiro: Civilização Brasileira, 2006. p. 145-147; FONTANA, Josep. Por el bien del imperio: una historia del mundo desde 1945. Barcelona: Pasado \& Presente, 2011. p. 42-50.

${ }^{19}$ LANCASTER, Carol. Foreign Aid: Diplomacy, Development, Domestic Politics. Chicago: The University of Chicago Press, 2007; KRIGE, John. American Hegemony and the Postwar Reconstruction of Science in Europe. Cambridge/Londres: MIT Press, 2006; ROBIN, Ron. The Making of the Cold War Enemy: Culture and Politics in the Military-Intellectual Complex. Princeton: Princeton University Press, 2001.

${ }^{20}$ Entre 1947 e 1954, o BIRD emprestou para a fins de reconstrução tão somente US\$ 800 milhóes, enquanto apenas o Plano Marshall concedeu a dezesseis países US\$ 13,5 bilhóes, dos quais mais de $90 \%$ em condiçóes altamente facilitadas, o que representou, na época, pouco mais de $4 \%$ do PIB americano. Cf. SOGGE, David. Dar y tomar: ¿qué sucede con la ayuda internacional? Barcelona: Icaria Editorial, 2002. p. 21-22.

${ }^{21}$ KAPUR, Devesh et al., op. cit., p. 129; KOFAS, Jon. Independence from America: Global Integration and Inequality. Burlington: Ashgate, 2005. p. 21; KIRK, Jason. India and the World Bank. Londres: Anthem, 2010. p. 7. ${ }^{22}$ MASON, Edward; ASHER, Robert, op. cit., p. 24; KOLKO, Gabriel. The Politics of War: the World and United States Foreign Policy, 1943-45. Nova York: Pantheon, 1990. p. 257.
} 
porque, para atrair interessados na compra dos seus títulos, a instituição adotou uma política de crédito pautada pela rentabilidade comercial. Os empréstimos do Bird tinham de gerar lucro e a forma considerada mais adequada para isso era financiar projetos de infraestrutura que demonstrassem para onde ia e como era empregado o dinheiro, o que, por sua vez, era usado como elemento de propaganda junto a investidores privados para que comprassem mais títulos do banco. É verdade que quando questôes políticas estavam em jogo, tal obrigatoriedade náo impediu que o banco camullasse créditos para aliviar crises em balanços de pagamentos como se fossem empréstimos para projetos específicos. ${ }^{23}$ Mas a regra, de todo modo, prescrevia empréstimos para projetos produtivos. Desse modo, até 1962, o Bird não autorizou nenhum empréstimo para a área "social", como saúde e educação. ${ }^{24}$ Os projetos elegíveis a financiamento tinham de ser lucrativos e efetuar os gastos predominantemente em dólar. Projetos para fins "sociais" não atendiam a tais exigências. ${ }^{25}$

Além disso, a confiança dos investidores de Wall Street nos títulos do Bird foi alimentada pelo fato de que os acordos de empréstimo da instituiçáo com os Estados clientes estabeleciam que os recursos deviam ser gastos na compra de bens e serviços de empresas situadas nos países mais ricos, o que, por sua vez, contribuía para manter elevado o nível de emprego no Norte. Assim, o banco cumpriu o papel de introduzir ou fortalecer a presença de empresas e bancos americanos e europeus no Terceiro Mundo. ${ }^{26}$

Logo o Bird começou a considerar seus projetos como veículos para a disseminaçáo de negócios lucrativos e prescrições sobre desenvolvimento junto à burocracia estatal nos países clientes. ${ }^{27}$ Em geral, isso se materializava na criação de agências específicas para administrar projetos, que funcionavam como verdadeiros enclaves dentro da administração pública. Também era comum o atrelamento da liberaçấo de recursos ao "bom comportamento" dos clientes em matéria de política econômica - p. ex., inexistência de atitudes hostis contra o capital estrangeiro, desvalorização cambial e equilíbrio orçamentário. ${ }^{28}$

Em outras palavras, nos seus primeiros anos o Bird se distinguiu tanto das agências americanas de ajuda econômica bilateral como de outras organizaçóes multilaterais (como a FAO, a Unesco e a OMS), para as quais agricultura, educação e saúde eram setores estra-

\footnotetext{
${ }^{23}$ KAPUR, Devesh et al., op. cit., p. 123.

${ }^{24}$ KAPUR, Devesh et al., op. cit., p. 119.

${ }^{25}$ GAVIN, Michael; RODRIK, Dani. The World Bank in historical perspective. American Economic Review, v. 85, n. 2, p. 333, maio 1995. Para uma discussão sobre o debate dentro do Banco nesse período, cf. ALACEVICH, Michele. The Political Economy of the World Bank: the Early Years. Palo Alto/Washington, DC: Stanford University Press/The World Bank, 2009.

${ }^{26}$ GOLDMAN, Michael. Imperial Nature: the World Bank and Struggles for Social Justice in the Age of Globalization. New Haven: Yale University Press, 2005. p. 30.

${ }^{27}$ KAPUR, Devesh et al., op. cit., p. 125-126.

${ }^{28}$ ASCHER, William. The World Bank and U.S. control. In: KARNS, Margaret; MINGST, Karen (Ed.). The United States and Multilateral Institutions: Patterns of Changing Instrumentality and Influence. Boston: Unwin Hyman, 1990. p. 117.
} 
tégicos. Por adotar um perfil conservador, baseado na rentabilidade comercial e no foco em projetos de infraestrutura, não havia subsídio nas suas operaçôes financeiras nem crédito para setores considerados não lucrativos. ${ }^{29}$ Isso não impediu que a instituição, sob orientação do Departamento de Estado ou do Departamento do Tesouro, concedesse ou negasse empréstimos para clientes segundo razôes de ordem política, nem evitou que as condições impostas para a autorização de empréstimos variassem de acordo com critérios políticos. ${ }^{30}$ Contudo, a preferência de Washington por conduzir operaçôes visivelmente políticas muito mais por canais bilaterais do que multilaterais criou uma margem de manobra para que o Bird se consolidasse como um ator financeiro fortemente ligado ao mercado de capitais americano, simbolizado por Wall Street, e sob roupagem técnica aparentasse certa distância da guerra fria.

\section{A criação da Associação Internacional de Desenvolvimento}

A criação da AID teve importância fundamental na trajetória ascendente do Banco Mundial. Para entendê-la é necessário considerar a série de fatores internacionais de ordem política e econômica que pressionavam o Bird na segunda metade dos anos 1950.

O primeiro tinha a ver com as tensôes políticas da Guerra Fria, alargada pelos processos de independência das colônias europeias na África e na Ásia — e a possibilidade de que nacionalismo e socialismo eventualmente convergissem nos Estados pós-coloniais - e pela revoluçấo cubana, encarada por Washington como um caso de metástase do comunismo na América Latina. Em paralelo, o movimento dos países não alinhados, ainda que internamente bastante heterogêneo e dividido politicamente, condenava com veemência o colonialismo e reclamava o "desenvolvimento" de seus países, dando visibilidade à crescente tensão Norte-Sul em torno da desigualdade de riqueza e poder entre os Estados e dentro das organizaçóes multilaterais.

O segundo fator consistia no questionamento crescente do papel do Bird como agência de financiamento do desenvolvimento. Para ganhar a confiança de Wall Street, o banco havia se fechado aos países pobres, considerados insolventes. Na prática, isso significava que a vasta maioria dos Estados pós-coloniais não tinha acesso à principal fonte multilateral de crédito e, pelas mesmas razóes, também tinham dificuldade para captar empréstimos junto a fontes privadas. Por outro lado, diversos governos de países de renda média - maiores clientes do banco depois da Índia — se queixavam de que as condiçóes de empréstimo do

\footnotetext{
${ }^{29}$ KAPUR, Devesh et al., op. cit., p. 188-189.

${ }^{30}$ KOFAS, Jon, op. cit., p. 7-28; The Sword of Damocles: U.S. Financial Hegemony in Colombia and Chile, 1950-1970. Westport: Praeger, 2002; . The politics of austerity: the IMF and U.S. foreign policy in Bolivia, 1956-1964, The Journal of Developing Areas, v. 29, n. 2, p. 213-35, jan. 1995; GARCÉS, Joan. Soberanos e intervenidos: estrategias globales, americanos y españoles. 3. ed. Madri: Siglo XXI, 2008. p. 106.
} 
Bird eram onerosas e criticavam a ausência, para eles, de crédito sob condiçôes concessionárias, como o Plano Marshall. ${ }^{31}$

O terceiro fator consistia no fortalecimento da campanha em prol da aprovação do Fundo Especial das Naçôes Unidas para o Desenvolvimento Econômico (Sunfed). Protagonizada por Índia, Chile e Iugoslávia, o objetivo era criar uma agência da ONU especializada em prover assistência financeira e técnica em termos concessionários que operasse segundo o princípio de um voto por Estado. Proposto em 1949, o projeto foi aprovado em 1952 pela Assembleia Geral da ONU, a despeito da oposição do governo dos EUA e de outras potências capitalistas, e em 1958 o Sunfed foi habilitado para financiar investimentos. ${ }^{32}$

Embora o governo Eisenhower (1953-1961), assim como o seu antecessor, fosse contrário ao financiamento concessionário ao Terceiro Mundo e mais ainda que isso se desse por meio de uma agência da ONU, os círculos dirigentes de Washington estavam cada vez mais preocupados com a escalada da Guerra Fria e as tentativas soviéticas de explorar dentro da ONU a tensão emergente entre Norte e Sul. ${ }^{33}$ A resposta veio em meados de 1959, quando o Tesouro americano propôs a criação da Associação Internacional de Desenvolvimento (AID). A partir de então, a expressão "Banco Mundial" designaria a junção do Bird com a AID.

Fundada em 1960, a AID era o oposto do Sunfed. Vinculada ao Bird, regia-se pelo mesmo sistema desigual de distribuição de voto e passava ao largo dos mecanismos de tomada de decisão da ONU. Ademais, suas atividades seriam financiadas por rodadas periódicas de doaçôes (chamadas de "reposiçôes") oriundas do jogo de interesses entre uns poucos Estados doadores. Seus empréstimos, ofertados em condiçóes altamente facilitadas, aliviariam a pressão para que o Bird emprestasse a países pobres. ${ }^{34}$ Como previsto, a Índia e o Paquistão - dois países estratégicos para a diplomacia americana na Ásia — se tornaram os seus maiores clientes.

Com a criação da AID, o governo americano e seus principais aliados europeus não apenas conseguiram inviabilizar o Sunfed, como passaram a contar com mais um instrumento de ajuda externa sob seu controle, num período de acirramento das tensóes políticas no Terceiro Mundo. Ao mesmo tempo, a vinculação da AID ao Bird, uma organização multilateral, foi importante para evitar a sua associação direta com a política externa americana. Ademais, a criação da AID forneceu para os EUA um meio adicional de compartilhamento da carga financeira da ajuda ao desenvolvimento com as demais potências capitalistas, no bojo do processo mais amplo de multilateralização crescente da ajuda externa que acompanhou a descolonização. Na perspectiva do governo americano, mais do que nunca a ajuda econômica bilateral e multilateral deveria ser ampliada, a fim de impedir a gravitação soviética e

\footnotetext{
${ }^{31}$ OLIVER, Robert. George Woods and the World Bank. Boulder: Lynne Rienner, 1995. p. 129; GWIN, Catherine, op. cit., p. 206; KAPUR, Devesh et al., op. cit., p. 1.126; LANCASTER, Carol, op. cit., p. 66.

${ }^{32}$ MASON, Edward; ASHER, Robert, op. cit., p. 382-386.

${ }^{33}$ GWIN, Catherine, op. cit., p. 205-206.

${ }^{34}$ KAPUR, Devesh et al., op. cit., p. 170.
} 
evitar a emergência de governos que, mesmo não alinhados à URSS, pudessem de algum modo assumir uma posição hostil aos EUA. ${ }^{35} \mathrm{~A}$ interação entre a política externa dos EUA e a atuação do banco se tornou ainda mais intensa, em particular em duas regióes: no sul da Ásia, onde os EUA passaram a desembolsar grandes somas de ajuda financeira ao Paquistáo e à Índia, e na América Latina, durante a Aliança para o Progresso. ${ }^{36}$

\section{Continuidades e inovações da gestão Woods (1963-1968)}

No início dos anos 1960, o banco se encontrava em condiçốes financeiras bastante sólidas. Contudo, dado o acelerado endividamento externo da grande maioria dos países da periferia, sobretudo os de renda média, ${ }^{37}$ o Bird se viu diante da escassez de clientes considerados solventes, o que era um problema sério náo apenas porque se tratava de uma organização baseada em empréstimos, mas também por questóes políticas e de imagem. ${ }^{38}$ Afinal, a ONU, por indicação do governo Kennedy (1961-1963), havia declarado os anos 1960 como a "década do desenvolvimento" e o número de Estados-membros do banco não parava de aumentar graças à AID, assim como aumentava o número de instituiçóes bilaterais e multilaterais capazes de fornecer créditos.

Foi nesse quadro que George Woods, ex-presidente do First Bank Boston, chegou à presidência do Banco Mundial. Sua gestão respondeu a tal contexto mediante o abrandamento dos critérios de solvência e a valorização de outros indicadores para a autorização de empréstimos, como o potencial de crescimento e o tipo de política econômica implementada. A entidade também passou a canalizar empréstimos em abundância para Estados cujos governos ditatoriais eram aliados dos EUA - Nicarágua, Brasil (depois de 1964), Espanha, Portugal, Indonésia (sob Suharto), Zaire, África do Sul, entre outros, sempre alegando para isso critérios de ordem meramente técnica. ${ }^{39}$

Por tudo, a carteira de empréstimos do banco aumentou cerca de 10\% ao ano entre 1963 e 1968, o orçamento administrativo mais do que triplicou e a instituição iniciou operaçôes em nada menos do que cinquenta novos países, dos quais metade na África subsaariana. ${ }^{40}$ Além disso, do ponto de vista setorial, os empréstimos para a agropecuária cresceram bastante e começaram os créditos para educação, abastecimento de água e saneamento básico.

\footnotetext{
${ }^{35}$ GWIN, Catherine, op. cit., p. 207-208; DEZALAY, Yves; GARTH, Bryant. La internacionalización de las luchas por el poder. México, DF: Instituto de Investigaciones Jurídicas/Universidad Nacional Autónoma de México, 2005. p. 101-110.

${ }^{36}$ KAPUR, Devesh et al., op. cit., p. 163-164.

${ }^{37}$ MASON, Edward; ASHER, Robert, op. cit., p. 221, nota 39.

${ }^{38}$ AYRES, Robert. Banking on the Poor: the World Bank and World Poverty. Londres: MIT Press, 1983. p. 3; KAPUR, Devesh et al., op. cit., p. 177.

${ }^{39}$ PAYER, Cheryl. The Debt Trap: the International Monetary Fund and the Third World. Nova York: Monthly Review Press, 1974; KOFAS, Jon, op. cit.; TOUSSAINT, Eric, op. cit., p. 83-98.

${ }^{40}$ KAPUR, Devesh et al., op. cit., p. 187-188.
} 
Até o início dos anos 1960, o programa do banco para a agricultura havia sido modesto. $\mathrm{O}$ aumento dos empréstimos para o setor foi puxado pelo envolvimento crescente - e decisivo — da instituição com a "revolução verde", i.e., o desenvolvimento de sementes híbridas (de trigo e, depois, arroz e milho) cuja alta produtividade dependia de condições ótimas de irrigação e do uso intensivo de pesticidas, fertilizantes químicos e máquinas agrícolas produzidos por empresas americanas e europeias. Sempre em associação com as fundações Rockefeller e Ford, e depois com a Usaid, o Banco Mundial cumpriria um papel fundamental não apenas financiando projetos agrícolas que demandassem esse novo pacote tecnológico, mas também patrocinando a criação de centros de pesquisa agrícola em diversos países do Terceiro Mundo durante os anos 1960, responsáveis por formar técnicos especializados para difundir as novas variedades. ${ }^{41}$

A produção das novas sementes dependia de um sofisticado e caro sistema de irrigação e da utilização de insumos industriais cuja eficiência máxima se dava a partir de certa escala, o que beneficiava os produtores mais ricos, mais instruídos e detentores das melhores terras. ${ }^{42}$ O acesso ao crédito agrícola e a serviços de assistência técnica se tornou indispensável. Para viabilizá-lo, fundos públicos nacionais e estrangeiros passaram a ser canalizados, fortalecendo elites agrárias e empresas agroquímicas. ${ }^{43}$ Enquanto os EUA e a Europa Ocidental subsidiavam os seus agricultores, os EUA, os países europeus e o Banco Mundial pressionavam os países subdesenvolvidos a adotarem a revolução verde mediante a compra de máquinas e insumos químicos produzidos nos países centrais. Isso contribuiu para o aumento da produção, mas também da dívida externa, abrindo adicionalmente as portas para a crescente dependência alimentar. ${ }^{44}$

A despeito da diversificação setorial e da extensão da atuação do Banco Mundial para países pobres, a visão predominante dentro da instituição sobre os benefícios gerais decorrentes do crescimento econômico náo se alterou. No início dos anos 1960, o credo do desenvolvimento estava em alta, alimentado pela onda expansiva do pós-guerra que incluía não apenas a Europa Ocidental e o Japão, mas também países da periferia, ainda que de forma altamente assimétrica. A crença no poder da tecnologia e da ciência parecia inexpugnável, dando suporte a uma concepção de desenvolvimento como função direta do investimento físico. ${ }^{45}$

De modo geral, havia sintonia entre os modelos de crescimento econômico em voga na academia americana e a pregação de Washington para que o Terceiro Mundo absorvesse mais ajuda econômica e empréstimos externos. O banco funcionava como uma caixa de

${ }^{41}$ PERKINS, John H. Geopolitics and the Green Revolution: Wheat, Genes, and the Cold War. Nova York: Oxford University Press, 1997.

${ }^{42}$ GEORGE, Susan. O mercado da fome. Rio de Janeiro: Paz e Terra, 1978. p. 111; LAPPÉ, Frances M.; COLLINS, Joseph. Comer és primero: más allá del mito de la escasez. México, DF: Siglo XXI, 1982. p. 115-122.

43 PAYER, Cheryl. The World Bank: a Critical Analysis. Nova York: Monthly Review Press, 1982. p. 207-245.

${ }^{44}$ KOFAS, Jon, op. cit., p. 24; SHIVA, Vandana. The Violence of Green Revolution. Londres: Zed Books, 1991. p. 171-194.

${ }^{45}$ KAPUR, Devesh et al., op. cit., p. 146-148. 
ressonância desse ideário. Assim, duas coordenadas intelectuais predominavam na instituição. ${ }^{46}$ A primeira postulava que a distribuição de renda se concentrava nos estágios iniciais do ciclo econômico e se desconcentrava nos estágios finais, de tal maneira que, após uma fase ascendente e sustentada de crescimento econômico, operar-se-ia o efeito derrame (trickle-down), i.e., o gotejamento gradual da renda para os estratos mais baixos da estrutura social. A segunda coordenada supunha a existência de trocas compensatórias (trade-offs) entre eficiência e distribuição, razão pela qual políticas distributivas eram vistas como prejudiciais ao crescimento.

Apesar da obsessão com o crescimento econômico, a escalada da guerra fria impôs ao Banco Mundial a realização de ajustes conceituais. Assim, convertido em questão política, ao longo da década o desenvolvimento deixou de ser sinônimo de mero aumento da capacidade produtiva, independentemente da localização, para se tornar algo cujo significado se aproximava da redução da desigualdade entre os países. ${ }^{47} \mathrm{O}$ mapa global era redesenhado então em dois eixos, superpondo-se à divisão Leste-Oeste a divisão Norte-Sul entre naçóes ricas e pobres.

Ao final dos cinco anos da gestão Woods, o banco havia concedido mais empréstimos do que nos dezesseis anteriores. Os critérios mais conservadores para concessão de empréstimos para projetos continuaram como referência, e a imagem do banco como emprestador baseado no mercado de capitais era bastante sólida, tanto que os títulos da instituição gozavam da máxima pontuação "AAA" atribuída pelas agências de credit rating de Wall Street. Todavia, houve uma suavização operacional na sua orientação de crédito, em virtude da necessidade de dar respostas às mudanças geopolíticas ocorridas no cenário internacional. Além de aumentar os desembolsos para a agricultura, na esteira da revoluçáo verde, o banco iniciou timidamente operaçóes nas áreas educacional e urbana. Em particular, aumentou bastante o componente de assistência técnica, ampliando a sua gravitação na vida econômica e política dos países-membros.

A primeira reposição de fundos da AID ocorreu ainda no governo Kennedy, num contexto de expansão da ajuda externa ao desenvolvimento. Já as negociaçôes para a segunda reposiçáo, iniciadas em 1966, ocorreram num quadro mais complicado. ${ }^{48}$ Àquela altura, o governo americano tomava medidas para controlar a inflação, reduzir a evasão de dólares e impedir ou minimizar a desvalorização da sua moeda. Ademais, para financiar a guerra do Vietnã e a corrida armamentista, o governo era obrigado a cortar programas domésticos e aumentar impostos. Crescia nos EUA a "fadiga da ajuda", i.e., a queda do apoio político, sobretudo no Congresso, à ajuda externa, cada vez mais considerada um instrumento

\footnotetext{
${ }^{46}$ KAPUR, Devesh et al., op. cit., p. 116-117; STERN, Nicholas; FERREIRA, Francisco. The World Bank as 'intellectual actor'. In: KAPUR, Devesh et al. (Ed.). The World Bank: its First Half Century - Perspectives. Washington, DC: Brookings Institution Press, 1997. v. 2, p. 530-532.

${ }^{47}$ KAPUR, Devesh et al., op. cit., p. 140.

${ }^{48}$ KAPUR, Devesh et al., op. cit., p. 211.
} 
caro e ineficiente para a promoção dos interesses americanos (políticos e econômicos) pelo mundo afora.

Para sustentar a expansão financeira do banco, Woods propôs uma reposição de um bilhão de dólares, com a qual o governo americano concordou..$^{49}$ As negociaçôes com os demais doadores foram encerradas e a proposta foi encaminhada ao Congresso para aprovaçáo. Woods deixou a presidência do banco no início de 1968, deixando ao seu sucessor, Robert McNamara - secretário de Defesa dos EUA desde 1961 — a tarefa de concluir o processo. A proposta enfrentou resistência no Congresso e as disputas se arrastaram, provocando o atraso na aprovaçáo dos recursos e obrigando outros doadores a aportarem fundos para evitar uma suspensão temporária dos créditos da AID. A partir da segunda reposiçáo, emergiu um padrão oriundo de pressóes ora do Legislativo — cada vez mais atuante —, ora do Executivo, pelo qual a cada rodada de negociação os EUA exigem concessóes para autorizar a sua contribuição à AID..$^{50}$ Assim, enquanto o Bird cada vez mais captava recursos em mercados de capitais fora dos EUA, tornando-se financeiramente menos dependente de Wall Street, a AID abria-se às vicissitudes da disputa política em Washington e entre os EUA e os demais doadores. Esse padrão se intensificaria nas décadas seguintes e seria utilizado pelos EUA para, paradoxalmente, aumentar a sua própria influência no banco. Como? Segundo Babb, ${ }^{51}$ uma das fontes mais importantes de influência americana na instituição desde então tem sido a relutância dos EUA em apoiá-lo. Nas negociaçóes para reposiçáo de fundos da AID, os EUA têm mais críticas e demandas e menos compromisso com acordos, além de serem o único membro importante que não aporta o financiamento prometido e permanece reiteradamente em atraso. No Congresso há tradicionalmente forte oposição a qualquer forma de multilateralismo e os governos aprenderam a usar a incerteza da aprovaçáo congressual a seu favor, utilizando-a para ameaçar ou barganhar com outros Estados e com a alta administração do banco; ou seja, utilizando constrangimentos internos para aumentar a sua alavancagem externa.

\section{A gestão McNamara: diplomacia do desenvolvimento e pobretologia (1968-1981)}

A chegada de McNamara à presidência do banco marcou profundamente a história da instituição. Evocando a conexão entre segurança e desenvolvimento como diretriz da sua gestão, McNamara afirmou que o atraso econômico e as contradiçôes da modernizaçáo capitalista abriam as portas para ideologias radicais. Daí a sua máxima: "Sem desenvolvimento interno, pelo menos em grau mínimo, ordem e estabilidade são impossíveis." 52

\footnotetext{
${ }^{49}$ OLIVER, Robert, op. cit., p. 230.

${ }^{50}$ GWIN, Catherine, op. cit., p. 209.

${ }^{51}$ BABB, Sarah. Behind the Development Banks: Washington Politics, World Poverty, and the Wealthy of Nations. Chicago: The University of Chicago Press, 2009. p. 13-16.

52 McNAMARA, Robert. A essência da segurança. Sáo Paulo: Ibrasa, 1968. p. 173.
} 
A rigor, tal abordagem não era nova e orientava programas aplicados com mais ou menos vigor na América Latina desde o começo da Guerra Fria, como o Desenvolvimento de Comunidade e, depois de 1961, a Aliança para o Progresso. ${ }^{53}$ A sua retomada no final dos anos 1960 tinha a ver com o reconhecimento por Washington do fracasso da via predominantemente militar seguida pelos EUA no Vietnã. ${ }^{54}$ Isso explica a ênfase do governo americano no aumento da assistência multilateral frente à ajuda bilateral, uma vez que, para Washington, o Banco Mundial e os demais bancos multilaterais de desenvolvimento (BMDs) podiam alavancar fundos e emprestar para países da periferia relevantes do ponto de vista geopolítico para os EUA sem atrair críticas diretas à política externa e sem o ônus econômico dos programas bilaterais.

Ao assumir o cargo, McNamara afirmou que o balanço da "década do desenvolvimento" era "desapontador", porque a desigualdade de renda entre as naçóes havia aumentado e a maior parte da população do planeta vivia em condiçôes de pobreza extrema, apesar da elevação das taxas de crescimento econômico em grande parte do mundo. ${ }^{55}$ Tudo isso implicava o reconhecimento de que os benefícios do crescimento não haviam escorrido para baixo, como pregava a doutrina do "efeito derrame". Assim, para McNamara, já não era mais válido supor que o crescimento levasse necessariamente à reduçáo da pobreza. Era preciso distingui-los conceitualmente e abordá-los de maneira separada e direta. Por outro lado, McNamara sempre negou que a diminuição da pobreza ocorresse à custa do crescimento, como afirmava a imensa maioria dos economistas naquela época (dentro e fora do banco), e insistiu na centralidade do crescimento. ${ }^{56}$

A consigna do "assalto à pobreza" figurou no centro do discurso da nova gestão. Em nome dela, a gestão McNamara mais do que duplicou a carteira de empréstimos. Houve ampliação considerável dos empréstimos para o setor agropecuário e, em menor grau, para fins "sociais", como educação, saneamento básico, nutrição, habitação urbana e planejamento familiar. Quanto à alocação geográfica, embora os desembolsos para a Ásia fossem intensificados, as operaçôes na África e na América Latina aumentaram proporcionalmente mais.

McNamara estabeleceu metas anuais de empréstimos para cada país e definiu que a eficiência profissional de cada funcionário seria avaliada segundo o volume de recursos envolvido nos projetos sob sua responsabilidade. O imperativo de "mover o dinheiro" a qualquer custo tornou-se, desse modo, um dos traços mais marcantes da cultura organizativa do banco.

\footnotetext{
${ }^{33}$ Cf. LANCASTER, Carol, op. cit.; LATHAM, Michael. Modernization as Ideology: American Social Science and "Nation Building" in the Kennedy Era. Chapel Hill/Londres: The University of Carolina Press, 2000; ESCOBAR, Arturo. La invención del Tercer Mundo: construcción y deconstrucción del desarrollo. Bogotá: Editorial Norma, 1996.

${ }^{54}$ KAPUR, Devesh et al., op. cit., p. 220.

${ }^{5}$ McNAMARA, Robert. A imposição do desenvolvimento. In: McNAMARA, Robert. Cem países, dois bilhóes de seres: a dimensão do desenvolvimento. Rio de Janeiro: Fundação Getulio Vargas, 1974. p. 4-5.

${ }^{56}$ KAPUR, Devesh et al., op. cit., p. 217.
} 
Como parte desse movimento expansivo e da crescente ênfase no setor rural, o banco se articulou às fundaçôes Ford e Rockefeller para criar uma rede internacional de centros de pesquisa agrícola que impulsionasse a difusão dos pacotes tecnológicos da revolução verde pelo mundo. ${ }^{57} \mathrm{~A}$ iniciativa culminou na criação do Grupo Consultivo para a Pesquisa Agrícola Internacional (CGIAR) em $1971 .{ }^{58}$ A malha de instituiçôes vinculadas ao CGIAR rapidamente se ampliou e se ramificou pelos âmbitos da ciência, da indústria da ajuda e do universo empresarial, fomentando e amalgamando interesses e concepçôes de mundo a respeito da organização da produção agropecuária e da alimentação humana. O intercâmbio promovido pelo CGIAR canalizou dólares para institutos nacionais de pesquisa por meio de parcerias com universidades americanas, jogando um papel crucial na americanização dos sistemas agroalimentares dos países clientes. ${ }^{59}$

A expansão da atividade financeira durante o primeiro quinquênio da gestão McNamara teve de enfrentar a vigilância crescente do Congresso sobre a ajuda externa do país. Antes do início dos anos 1970, o Congresso havia se limitado a um papel meramente passivo. ${ }^{60}$ Porém, com a guerra do Vietnã e o fim do consenso bipartidário sobre a política externa, e num período em que a economia enfrentava problemas domésticos graves, a crítica congressual à utilidade da ajuda bilateral aumentou. Para driblar o aumento da ingerência do Congresso sobre a ajuda bilateral, o Executivo passou a dar mais peso, em termos relativos, à assistência multilateral, modalidade mais difícil de ser supervisionada e de maior aparência técnica. ${ }^{61}$

Contudo, à medida que os pedidos de fundos cresciam aceleradamente para os BMDs, o Congresso também voltou a sua atenção para eles. No caso do Banco Mundial, parlamentares e grupos de interesse diversos começaram a exigir informaçóes e a fazer exigências para a liberação de recursos, pluralizando a relação do banco com os atores sociais, políticos e econômicos dos EUA. Assim, além do Tesouro e do Departamento de Estado, cada vez mais o banco teve de responder ao Congresso, um espaço menos opaco e mais permeável a campanhas públicas do que o Executivo. Junto com o aumento do controle do Congresso sobre a ajuda bilateral surgiu gradualmente um extenso corpo legislativo sobre a relação dos EUA com o banco. ${ }^{62}$ Esse processo avançaria ininterruptamente dali em diante.

Em outras palavras, durante os primeiros cinco anos da gestáo McNamara, a expansão da atividade financeira do banco se deu em meio à queda do apoio à ajuda ao desenvolvimento nos EUA. Além de dificuldades crescentes para o banco obter recursos do seu

\footnotetext{
${ }^{57}$ MASON, Edward; ASHER, Robert, op. cit., p. 574; KAPUR, Devesh et al., op. cit., p. 399.

${ }^{58}$ KAPUR, Devesh et al., op. cit., p. 401.

${ }^{59}$ GOLDMAN, Michael, op. cit., p. 86-87.

${ }^{60}$ SCHOULTZ, Lars. Politics, Economics, and U.S. Participation in Multilateral Development Banks. International Organization, v. 36, 1982; GWIN, Catherine, op. cit., p. 211-212.

${ }^{61}$ De 1968 a 1970, três forças-tarefas sobre ajuda externa (as comissóes Perkins, Pearson e Peterson) recomendaram que os EUA enfrentassem a "fadiga de ajuda" aumentando a ajuda multilateral. Nixon anunciou essa estratégia em 1970. Cf. BABB, Sarah, op. cit., p. 56.

${ }^{62}$ GWIN, Catherine, op. cit., p. 220.
} 
principal acionista, o ativismo cada vez maior do Congresso em matéria de política externa criou oportunidades e meios para que críticas à participação dos EUA nos BMDs e à atuação dessas instituiçóes de fato as impactassem financeiramente. A falta de transparência do banco começou a ser objeto de interpelação legislativa frequente, particularmente no Appropriations Committee da Casa dos Representantes. Muitos congressistas passaram a duvidar de que o banco fosse um instrumento útil à segurança nacional dos EUA. A cada rodada de negociação para reposição de fundos da AID havia pressóes e barganhas entre os EUA e os demais doadores, no plano internacional, e entre o Tesouro, o Departamento de Estado e o Congresso, no plano doméstico.

A expansão financeira do banco foi acompanhada de investimento em pesquisa econômica. Até o início dos anos 1970, essa atividade havia sido pouco expressiva e subfinanciada, com pouca ou nenhuma influência no âmbito operacional. ${ }^{63}$ A nomeação de Hollis Chenery para o novo cargo de economista-chefe em maio de 1970 foi o início de uma virada decisiva, que culminaria, em menos de uma década, na consolidação da instituição como referência obrigatória em pesquisa sobre desenvolvimento.

O tema da pobreza foi posto no centro da investigação do banco. Até então, enquanto questão teórica, a pobreza era assunto praticamente desconsiderado pela literatura econômica, figurando de modo vago e pejorativo, frequentemente associado à beneficência e ao assistencialismo ${ }^{64}$ A própria palavra não fazia parte do vocabulário corrente do staff do banco.

Para Washington e McNamara, a redução da pobreza no Terceiro Mundo estava ligada à luta contra o comunismo e à promoção da segurança dos EUA, vista como condição para a segurança do "mundo livre". Mas não só. Durante os anos 1970, a emergência do nacionalismo em países da periferia atormentou os policymakers da indústria internacional da ajuda. Dentro de organizaçóes como a Cepal e a Unctad, a opinião era a de que a solução para os dilemas do desenvolvimento (concentração de renda, pauperizaçáo e desigualdade entre as naçôes) passava por alguma redistribuição de recursos do Norte para o Sul. A Unctad, em particular, pressionava os países ricos para que aumentassem a ajuda financeira concessionária e apoiassem a estabilização dos preços das commodities e acordos comerciais que minimizassem a deterioração dos termos de intercâmbio. Como resultado de pressóes diversas e na esteira do choque do petróleo de 1973, a proposta de uma "nova ordem econômica internacional" acabou sendo encampada pela Assembleia Geral da ONU em 1974, incluindo demandas pela soberania do Terceiro Mundo sobre recursos naturais, aumento da ajuda ao desenvolvimento, alívio da dívida externa e aumento da voz no FMI e nos BMDs. ${ }^{65}$

\footnotetext{
${ }^{63}$ MASON, Edward; ASHER, Robert, op. cit., p. 467.

${ }^{64}$ FINNEMORE, Martha. Redefining development at the World Bank. In: COOPER, Frederick; PACKARD, Randall (Eds.). International Development and the Social Sciences. Berkeley: University of California Press, 1997. p. 207; KAPUR, Devesh et al., op. cit., p. 247.

${ }^{65}$ BABB, Sarah, op. cit., p. 55; GWIN, Catherine, op. cit., p. 216.
} 
A consigna da "luta contra a pobreza", assim, configurava um tipo de resposta - muitíssimo limitada e conservadora, é verdade - a uma miríade de reclames "sociais".

Com raízes diretas nas injunçóes da Guerra Fria e enxertada no banco a partir de Washington, o "assalto à pobreza", porém, careceu de dois elementos importantes naqueles anos: uma teoria e um meio passível de replicação e avaliação. Com efeito, o banco não tinha uma abordagem que conferisse coerência, para fora e para dentro, aos projetos que a instituição já vinha executando em agricultura, educação e habitação urbana, e também não tinha um instrumento que permitisse a mensuração de resultados. Ambos surgiram somente no biênio 1973-1974, com a definiçáo da "pobreza rural absoluta" como alvo principal da intervenção do banco por meio dos novos projetos de "desenvolvimento rural integrado", e com a publicação de um livro organizado por Chenery. ${ }^{66}$ Daí nasceu o enfoque "orientado à pobreza”.

Além da macropolítica da Guerra Fria e da necessidade, segundo os policymakers de Washington, de prevenir ou desativar o ativismo social dos camponeses no Terceiro Mundo, ${ }^{67}$ a construçáo desse enfoque seria impensável sem o questionamento ao "efeito derrame" por dentro do próprio mainstream econômico. ${ }^{68}$ Diversos dados apoiavam esse ceticismo, ligados ao aumento demográfico acelerado, à piora na distribuição de renda e ao crescimento limitado do emprego industrial. Alguns dos modelos em voga levavam à conclusão de que crescimento e desigualdade eram inseparáveis, e apesar da ideia de que a desigualdade "depois" diminuiria à medida que o desenvolvimento ocorresse, aumentou o debate sobre se a desigualdade aumentaria a tal ponto que minaria a redução da pobreza ${ }^{69}$

Também se deve levar em conta a mudança na política de ajuda externa dos EUA. As críticas acadêmicas se somavam àquelas veiculadas pelo Congresso sobre a condução da política externa, centrada na Guerra do Vietnã. Daí a aprovação, em 1973, do Foreign Assistance Act" ${ }^{70}$ Pautada pela ideia de "necessidades básicas", a nova diretriz tinha como foco a redução da "pobreza extrema" mediante a concessáo de crédito para o aumento da produtividade de "pequenos agricultores". Tais diretrizes repercutiram na busca, pela gestáo McNamara, de maior coerência entre a sua retórica pro-poor e a eficácia de projetos com esse fim.

Internamente, um passo decisivo para a construção do enfoque foi a definição da "pobreza absoluta" como unidade de análise e critério operacional..$^{71} \mathrm{~A}$ novidade dava suporte operacional à identificação de "focos de pobreza" no meio rural, que deveriam, então, ser

\footnotetext{
${ }^{66}$ CHENERY, Hollis. Redistribution with Growth. Londres: Oxford University Press, 1974.

${ }^{67}$ HUNTINGTON, Samuel. A ordem politica nas sociedades em mudança. São Paulo/Rio de Janeiro: USP/ Forense Universitária, 1975. p. 302.

${ }^{68}$ FINNEMORE, Martha, op. cit., p. 208.

${ }^{69}$ KANBUR, Ravi; VINES, David. The World Bank and poverty reduction: past, present and future. In: GILBERT, Christopher; VINES, David (Eds.). The World Bank: Structure and Policies. Cambridge: Cambridge University Press, 2000. p. 88-92.

${ }^{70}$ AYRES, Robert, op. cit., p. 9; BABB, Sarah, op. cit., p. 51.

${ }^{71}$ KAPUR, Devesh et al., op. cit., p. 239-240.
} 
"atacados" mediante projetos de "desenvolvimento rural integrado" que financiassem a aquisição e aplicação de pacotes tecnológicos por "pequenos agricultores". Ou seja, tratava-se de implementar uma espécie de "pequena revolução verde" em parcelas do campesinato, ${ }^{72}$ a fim de aumentar a sua produtividade econômica, expandir as relaçôes de mercado no meio rural, reduzir a pobreza, incutir o senso de propriedade privada e, por tudo isso, engendrar um ambiente ideologicamente refratário a ideologias "radicais". A concentração da propriedade da terra foi tomada como um dado ao qual os projetos deveriam se acomodar. ${ }^{73}$

Publicado no ano seguinte, Redistribuição com crescimento deu ao banco um núcleo teórico que lhe permitiu vender com mais eficácia seu novo produto, ao instituir a pobreza absoluta e os grupos-alvo como categorias operacionais legítimas para políticas públicas. A rigor, o livro prescrevia uma estratégia distributiva de tipo incremental, na medida em que se limitava a distribuir parte do crescimento econômico (rendas e ativos novos) mediante projetos e programas financiados através de captaçáo de impostos e endividamento externo. Em tese, tais açôes fomentariam o aumento da "produtividade dos mais pobres", de tal forma que, por meio da inserçáo atomizada no mercado, a sua renda aumentaria. O estoque de riqueza permaneceria intocável.

Em termos mais amplos, o livro ajudou a construir as bases de uma "ciência da pobreza" — uma pobretologia —, pautada pela centralidade da pobreza como categoria de análise e objeto da ajuda ao desenvolvimento. O engajamento crescente do banco na produçáo, compilação e disseminação de indicadores econômicos e referências metodológicas contribuiu para afirmar e amalgamar ideias e práticas a respeito da pobreza como fenômeno mensurável e quantificável. Ao mesmo tempo, o banco se articulou com outras agências multilaterais e instituiçóes nacionais de pesquisa e planejamento, difundindo a sua expertise e, assim, definindo gradativamente os termos legítimos do debate internacional sobre o tema. ${ }^{74}$

A tese de que a superação da pobreza rural se daria pelo aumento da "produtividade dos pobres" pressupunha que vivia na pobreza apenas quem não estivesse inserido em atividades produtivas e rentáveis. Assim, a pobreza era tomada como um fenômeno inteligível em si mesmo e como produto da exclusão do desenvolvimento econômico, e não como um dos seus resultados. ${ }^{75}$ Posta dessa maneira, a "luta contra a pobreza" parecia autoexplicativa e legítima por si própria.

Ao mesmo tempo que deslanchava os projetos de desenvolvimento rural integrado, a gestão McNamara se engajou na procura por um instrumento análogo para o meio urbano, pautado nas noçôes de focalização e produtividade. Os primeiros projetos do banco, ainda

\footnotetext{
${ }^{72}$ FEDER, Ernest. La pequena revolución verde de McNamara. Comercio Exterior, v. 26, n. 7, p. 793, 1976; GEORGE, Susan, op. cit., p. 238.

${ }^{73}$ AYRES, Robert, op. cit., p. 104.

${ }^{74}$ GOLDMAN, Michael, op. cit., p. 77-81; FINNEMORE, Martha, op. cit., p. 208.

${ }^{75}$ ASSMANN, Hugo. El "progresismo conservador" del Banco Mundial. In: ASSMANN, Hugo (Ed.). Banco Mundial: un caso de "progresismo conservador". San José: DPI, 1980. p. 47.
} 
em 1972, seguiam o enfoque de terrenos e serviços (sites and services), cujo objetivo era conciliar máxima recuperação de custos (sob a forma de cobrança de taxas) com mínimo subsídio público. Tratava-se, pois, de demonstrar a viabilidade de um modelo da habitação urbana de baixo padrão que fosse autofinanciável. O procedimento básico consistia em limitar ao mínimo possível a provisão pública para a compra da terra e a construção de infraestrutura básica, deixando aos novos proprietários a responsabilidade pela construção das casas e grande parte dos custos. Tal enfoque fornecia um meio para se explorar o trabalho não pago, rebaixar o custo de reproduçáo da força de trabalho e alimentar o conformismo social através do acesso à propriedade. ${ }^{76} \mathrm{Na}$ sequência, surgiu o enfoque da "urbanizaçáo de favelas" (slum upgrading), que demandava o mínimo de demoliçâo física e reassentamento de pessoas, com a vantagem de servir plenamente à canonização da habitação favelada, ao discurso do "ajudar os pobres a ajudarem a si próprios" e à ilusão incremental do "construa você mesmo".77

Entre 1976-1979, o banco entrou no debate sobre "necessidades básicas". A discussão foi lançada pela OIT e prometia dar peso à "necessidade" como critério para a alocação de recursos. A gestão McNamara debateu quais seriam as necessidades de fato "básicas", como justificá-las em termos de custo-benefício e como saber se o crescimento não seria mesmo prejudicado. ${ }^{78}$ Afinal, o próprio McNamara negava trade-offs entre crescimento econômico e reduçáo da pobreza. O debate não chegou a lugar algum e pouco se traduziu em projetos. ${ }^{79}$ Além de se acomodar à teoria do derrame,$^{80}$ a satisfação de necessidades básicas também era tomada como um objeto isolado do conjunto das relaçôes sociais e da política econômica, eludindo a questáo do desemprego e dos baixos salários.

Porém, a consequência mais importante desse debate foi a consagração de saúde e educação primárias como áreas financiáveis e prioritárias. O banco seguiu nessa linha, ligando-as ao combate à pobreza e à reconfiguração das políticas sociais. No final de 1979, a instituição começou a autorizar empréstimos exclusivamente para a saúde. Enquanto isso, o conceito de capital humano era entronizado tardiamente na agenda educacional da entidade. Em 1980, o Relatório sobre Desenvolvimento Mundial (RDM) ${ }^{81}$ sacramentou as duas novas prioridades na área social. Desenhavam-se entâo as coordenadas principais de um modelo de política social que se tornaria hegemônico uma década depois, centrado na formação de capital humano e na prestação de mínimos sociais pelo Estado.

\footnotetext{
${ }^{76}$ ARANTES, Pedro Fiori. O ajuste urbano: as políticas do Banco Mundial e do BID para as cidades latino-americanas. Dissertação (Mestrado em Arquitetura e Urbanismo) — Programa de Pós-graduação em Arquitetura e Urbanismo, Universidade de Sáo Paulo, 2004. p. 33.

77 DAVIS, Mike. Planeta Favela. São Paulo: Boitempo, 2006. p. 80-81. Sobre as contradiçóes da aplicação desses enfoques para o Banco, cf. KAPUR, Devesh et al., op. cit., p. 317-319.

${ }^{78}$ AYRES, Robert, op. cit., 85-89.

${ }^{79}$ KAPUR, Devesh et al., op. cit., p. 265-267.

${ }^{80}$ STREETEN, Paul et al. Lo primero es lo primero. Madri: Tecnos/Banco Mundial, 1986. p. 95-105.

${ }^{81}$ A série de RDMs teve início em 1978 e, desde então, trata-se da publicação anual mais importante do Banco. É um guia de políticas econômicas e setoriais sob a aparência da melhor pesquisa técnica.
} 
Qual balanço se pode fazer da "cruzada contra a pobreza" de McNamara? Em primeiro lugar, os empréstimos do banco para projetos com algum componente (não necessariamente majoritário) "orientado à pobreza" oficialmente não ultrapassaram um terço do total. Entretanto, esta cifra está superestimada, pois o staff exagerava o grau de cobertura dos projetos, aumentando o número de beneficiários considerados pobres, uma vez que a ascensão profissional dependia do volume de empréstimos sob supervisão de cada funcionário. ${ }^{82}$

Em segundo lugar, quando comparados à magnitude do investimento público realizado pelos Estados clientes, os empréstimos do banco sempre representaram uma quantia irrisória. De fato, o impacto da atuaçáo da entidade se concentrava na formação de ideias e práticas sobre a gestão econômica e social. ${ }^{83}$ Dessa perspectiva, o financiamento era mais importante como alavanca para induzir mudanças no gasto público e em políticas públicas do que como crédito em si. ${ }^{84}$ Isto porque, para cada empréstimo contratado, os Estados tinham de desembolsar uma contrapartida financeira, em geral muito maior; depois, precisavam pagar ao banco, tido sempre como credor preferencial, e em moeda forte. Em muitos casos, agências da administração pública responsáveis pela regulação de setores inteiros da economia foram erguidas a partir de empréstimos e/ou assessoria técnica do banco. Com frequência, esse processo teve conotaçóes políticas preventivas ou reativas de perfil conservador, servindo para que governos eludissem a pressão popular por reformas redistributivas.

\section{Surgimento e dinâmica da política de ajustamento estrutural (1980-1989)}

De 1973 a 1979, uma série de eventos modificou sensivelmente a economia política mundial. Desde o final dos anos 1960, as contradiçôes do sistema monetário internacional tornavam a manutençáo da convertibilidade do dólar em ouro cada vez mais difícil para os EUA. Como resposta, o governo dos EUA rompeu unilateralmente com o regime monetário de Bretton Woods que o próprio poder americano havia criado em 1944, mediante uma série de medidas praticadas entre 1971 e $1974 .{ }^{85}$ Por sua vez, em 1979, junto com o segundo choque internacional do petróleo, o Tesouro aumentou brusca e agudamente a taxa de juros dos EUA, a fim de conter a inflação doméstica e impulsionar a retomada da supremacia do dólar no sistema monetário internacional. Combinada à liberalizaçâo do fluxo de capitais, a medida forçou a sobrevalorização do dólar e redirecionou a liquidez internacional para os

\footnotetext{
${ }^{82}$ KAPUR, Devesh et al., op. cit., p. 339.

${ }^{83}$ CAUFIELD, Catherine. Masters of Illusion: the World Bank and the Poverty of Nations. Nova York: Henry Holt, 1996. p. 97-98.

${ }^{84}$ KAPUR, Devesh et al., op. cit., p. 271.

${ }^{85}$ GOWAN, Peter, op. cit., p. 45-50; FONTANA, Josep, op. cit., p. 455-457; BRENNER, Robert. O boom e a bolha: os Estados Unidos na economia mundial. Rio de Janeiro: Record, 2003. p. 67-73; FIORI, José Luís. O poder global dos Estados Unidos: formação, expansão e limites. In: (Org.). O poder americano. Petrópolis: Vozes, 2004. p. 89-94.
} 
EUA, submetendo a política econômica de todos os demais países capitalistas, concorrentes e aliados, a um ajuste recessivo sincronizado com a política americana. Em pouco tempo, a flutuação das taxas de juros e câmbio voltou a estar atrelada ao dólar e, por meio dela, o movimento da liquidez internacional foi subordinado à política fiscal americana. Os títulos da dívida pública dos EUA se tornaram o ativo líquido por excelência da economia internacional, obrigando os detentores de excedentes financeiros a adquiri-los. Punha-se em marcha, assim, a "diplomacia do dólar forte". ${ }^{86}$

O início dos governos de Thatcher na Grã-Bretanha (1979) e Reagan nos EUA (1981) se deu nesse contexto e foi decisivo para promover uma guinada liberal-conservadora radical no ambiente político mundial. Para essa nova direita, dado o fim da onda expansiva da economia internacional no pós-guerra, a recuperação do crescimento econômico e do lucro privado passava pela demoliçáo do Welfare State. ${ }^{87}$ Ao mesmo tempo, no plano internacional, o eixo anglo-americano passou a impulsionar a liberalização das economias nacionais, combinando a "diplomacia do dólar forte" com uma ofensiva político-militar liderada pelos EUA contra a URSS.

Naquele momento, a atuação do banco consistia em firmar o "ajustamento estrutural" como meio necessário para a adaptação dos países endividados às novas condiçóes da economia política internacional. A expressão designava uma nova modalidade de empréstimo da instituição criada em maio de 1979, de desembolso rápido e orientada para políticas, e não para projetos. A autorização desse tipo de operação estava condicionada ao acordo prévio dos mutuários com o FMI para a realização de programas de estabilização monetária e reformas na política macroeconômica, a fim de adequar a economia doméstica ao novo ambiente externo e manter o pagamento do serviço da dívida. O primeiro empréstimo desse tipo foi aprovado em março de 1980 para a Turquia e constituiu um "protótipo" para os seguintes. ${ }^{88}$

Àquela altura, o programa de ajuste do banco consistia, em linhas gerais, na mesma agenda monetarista aplicada pelo FMI desde os anos 1960, porém com algumas novidades. ${ }^{89}$ No âmbito das políticas macroeconômicas, tratava-se de: liberalizar o comércio, alinhar os preços ao mercado internacional e baixar tarifas de proteção; desvalorizar a moeda; fomentar a atraçáo de investimento externo; expandir as exportaçôes, sobretudo agrícolas. Já no âmbito das políticas sociais e da administração estatal, o ajuste tinha como meta central a reduçáo do déficit público, especialmente por meio de medidas como: a) o corte de gastos com pessoal e custeio da máquina administrativa; b) a redução drástica ou mesmo a eliminação de subsídios ao consumo; c) a redução do custo per capita dos programas, a fim

${ }^{86}$ TAVARES, Maria da Conceição. A retomada da hegemonia norte-americana. In: ; FIORI, José Luís (Org.). Poder e dinheiro: uma economia política da globalização. Petrópolis: Vozes, 1997. p. 27-53.

${ }^{87}$ HOBSBAWM, Eric, op. cit., p. 245.

${ }^{88}$ KAPUR, Devesh et al., op. cit., p. 548.

${ }^{89}$ LICHTENSZTEJN, Samuel; BAER, Mônica, op. cit., p. 196-199; BROWN, Michael Barrat. Africa's Choices after Thirty Years of the World Bank. Boulder: Westview Press, 1995. p. 68-69. 
de ampliar o grau de cobertura; d) a reorientação da política social para saúde e educação primárias, mediante a focalização do gasto na parcela da população em condiçôes de "pobreza absoluta”.

Em agosto de 1982, o governo do México declarou moratória e a crise da dívida estourou. Era o ponto culminante de um processo de endividamento praticado exaustivamente durante mais de uma década com os bancos privados americanos e europeus, sob a conivência do FMI e do Banco Mundial. ${ }^{90}$ Solução prescrita: manter o serviço da dívida em dia, não reduzir a carga da dívida e baixar a diferença entre a dívida e o serviço, promovendo ajustes internos voltados à reorientação da produção para bens exportáveis, por meio da redução e do redirecionamento do gasto público. ${ }^{11}$ Os empréstimos de ajuste estrutural do banco, já em curso, foram instrumentalizados para servir ao enquadramento da política econômica dos devedores. Mecanismos de proteção ou compensação parcial a grupos sociais mais vulneráveis ao ajuste não foram cogitados.

O discurso do banco sobre o endividamento mudou completamente após a moratória mexicana. ${ }^{92}$ As causas externas foram secundarizadas e a responsabilidade pela crise foi atribuída a políticas econômicas erradas. Ou seja, a problemas internos decorrentes de má gestão econômica.

O escopo e a abrangência das condicionalidades exigidas pelo banco e pelo FMI foram desenhados conforme as decisóes dos principais atores envolvidos na gestão da crise. Entre 1982 e 1986, o objetivo central dos programas de ajustamento consistia na estabilização macroeconômica de curto prazo, deixando em segundo plano as reformas políticas de médio e longo prazo. O enfoque adotado foi o do "tratamento de choque", segundo o qual quanto mais cedo, rápido e forte fosse implementado o pacote, menor seria o desgaste político do governo. Tal enfoque era coerente com a visão de que se tratava de um ajuste de curto prazo.

Temas como o perdão da dívida e os impactos sociais do ajuste viraram verdadeiros tabus dentro do banco. Em plena era Reagan-Thatcher, a pesquisa do banco foi redirecionada para os defeitos do Estado e a eficiência dos mercados e para a contraposição entre equidade e eficiência. Expoentes da velha geração da Economia do Desenvolvimento foram substituídos por nomes associados à monoeconomia neoclássica, a fim de que fosse cumprida a "linha oficial do partido". ${ }^{93} \mathrm{O}$ centro doutrinário e operacional passou a ser a promoção da liberalização econômica radical. A própria ideia de desenvolvimento deu lugar à vigilância sobre a "performance" macroeconômica e fiscal dos mutuários.

${ }^{90}$ STRANGE, Susan. Dinero loco: el descontrol del sistema financiero global. Buenos Aires: Paidós, 1999. p. 121; WOODS, Ngaire. The Globalizers: the IMF, the World Bank and their Borrowers. Ithaca: Cornell University Press, 2006. p. 84-94; TOUSSAINT, Eric, op. cit., p. 185.

${ }^{91}$ TOUSSAINT, Eric, op. cit., p. 193; STERN, Nicholas; FERREIRA, Francisco, op. cit., p. 560.

${ }^{92}$ Basta comparar os RDMs de 1980 a 1982 com o de 1983, finalizado após a moratória mexicana.

${ }^{93}$ STERN, Nicholas; FERREIRA, Francisco, op. cit., p. 598; BABB, Sarah, op. cit., p. 82-84; GEORGE, Susan; SABELLI, Fabrizio. La religión del crédito: el Banco Mundial y su imperio secular. Barcelona: Intermón. 2. ed. 1996. p. 163-175. 
A crise financeira se aprofundou e, em resposta, o governo americano anunciou em 1985 uma revisão da estratégia de gestão da dívida, o Plano Baker. Junto com ele, o Tesouro definiu as prioridades que o banco deveria seguir na promoção do ajuste. Além do pacote tradicional de medidas na área macroeconômica e financeira, ganharam relevo a remodelagem do gasto público pela via da descentralização e, sobretudo, a privatização de empresas públicas. As condicionalidades exigidas pelo banco, então, estenderam-se a essas novas áreas. Em pouco tempo, o banco e o FMI substituíram os bancos privados como credores principais.

À medida que se avolumavam efeitos socialmente regressivos decorrentes dos planos de estabilização monetária e das medidas de ajuste, cresceu entre os gestores internacionais da crise a preocupação com a sustentabilidade política do processo em curso. Até então, o discurso oficial tinha sido de que o ajuste simplesmente era "bom para os pobres", pois os beneficiaria diretamente por meio do "efeito derrame". Esse discurso mudou em meados dos anos 1980, quando o banco começou a admitir a ocorrência de certos "custos sociais". A partir de 1986, o modus operandi do ajuste requereria a criação de programas paliativos de compensação social para aliviar, de maneira focalizada e no curto prazo, o impacto sobre as parcelas da população mais golpeadas ou mais suscetíveis a apoiarem a oposição.

Com o início do governo de George Bush em 1989, o Tesouro elaborou uma nova estratégia de gestão da dívida externa, materializada no chamado Plano Brady. As instituiçóes de Bretton Woods seguiram as orientaçóes do Tesouro e do Federal Reserve, autorizando novos empréstimos condicionados à abertura comercial prévia. ${ }^{94}$ No mesmo ano, pela primeira vez, $\mathrm{o}$ banco defendeu a desregulação financeira ampla, insistindo na eliminação de todos os instrumentos de controle sobre taxas de juros e programas de crédito dirigidos à atividade industrial.

No final de 1989, as principais forças que impulsionavam a liberalização da economia internacional realizaram na capital americana uma reunião para avaliar os resultados alcançados e planejar os próximos passos. Os participantes integravam a cúpula da rede de poder político, financeiro e intelectual do circuito Washington-Wall Street. Além de congressistas, estavam lá representantes do Tesouro, do Banco Mundial, do FMI, do BID, da Usaid e dos principais think tanks americanos. O pacote de dez reformas de política econômica ali sistematizado ficou conhecido como Consenso de Washington (CW). ${ }^{95}$

Construído sobre as ruínas do muro de Berlim, tal decálogo expressava a convergência entre o mainstream neoclássico, o governo dos EUA e os interesses financeiros simbolizados por Wall Street. ${ }^{96}$ Rapidamente, o CW ganhou o status de paradigma político transnacional, ${ }^{97}$

\footnotetext{
${ }^{94}$ GWIN, Catherine, op. cit., p. 235-236.

95 WILLIAMSON, John. What Washington means by policy reform. In:

Adjustment: How Much has Happened. Washington, DC: IIE, 1990. p. 5-20. (Org.). Latin American

${ }^{96}$ GUILHOT, Nicolas. The Democracy Makers: Human Rights and the Politics of Global Order. Nova York: Columbia University Press, 2005. p. 197.

${ }^{97} \mathrm{BABB}$, Sarah. The Washington Consensus as transnational policy paradigm: Its origins, trajectory and likely successor. Review of International Political Economy, v. 20, n. 2, p. 268-297, 2013.
} 
centrado na liberalização da economia mundial e na reorientação do Estado como provedor de um marco normativo que garantisse a segurança e a lucratividade dos negócios privados. ${ }^{98}$ Se, do ponto de vista internacional, o CW expressava o fim da tolerância de Washington com o nacionalismo econômico, do ponto de vista social o novo ideário encarnava a ofensiva do capital contra direitos sociais e trabalhistas consolidados no pós-guerra.

\section{Do Consenso de Washington à crise financeira do México (1989-1994)}

O fim da Guerra Fria e, logo, a desintegração da URSS, abriram um campo de atuaçáo enorme e promissor para o banco. Rapidamente, o número de clientes naquela região passou de vinte, respondendo por quase um quarto da carteira do Bird entre 1991 e $1995 .{ }^{99}$ Os empréstimos de ajuste estrutural e suas inúmeras condicionalidades desempenharam um papel central na transição capitalista, em clave neoliberal, e na pilhagem da riqueza nacional, proporcionada pela combinação de privatização agressiva com liberalizaçáo comercial e financeira unilateral. A contraface desse processo foi a deterioração dramática das condiçóes de vida da população, provocada por contraçáo dos salários, corte drástico no financiamento de serviços públicos essenciais, aumento do desemprego e queda geral da atividade econômica. ${ }^{100}$

Na virada dos anos 1980 para os 1990, o banco desenvolveu quatro coordenadas estratégicas que orientariam a sua ação política, intelectual e financeira nos anos seguintes. A primeira delas foi a difusão de um modelo de política social centrado no alívio da pobreza coerente com o ajuste macroeconômico. Em 1990, a pobreza foi o tema do RDM.101 Enfatizando a relação entre desigualdade internacional, pauperização e instabilidade política, o RDM partia da premissa da separação entre políticas "social" e "econômica". Ancorado na categoria da "pobreza absoluta" herdada dos tempos de McNamara, o relatório deixava de lado a questáo da concentraçáo de renda e riqueza e propunha uma estratégia dual, que combinava programas focalizados com uma confiança renovada nas virtudes redentoras do "efeito derrame", o qual, segundo o relatório, dependia da implementação das políticas orientadas ao mercado. $\mathrm{O}$ banco, assim, começava a sair da pauta macroeconômica estreita da era Reagan e voltar ao tema da pobreza do período McNamara, mas num caminho coerente com o ajuste e funcional à sua expansão. ${ }^{102}$

\footnotetext{
${ }^{98}$ WADE, Robert. Japón, el Banco Mundial y el arte del mantenimiento del paradigma: el Milagro del Este Asiático en perspectiva política. Desarrollo Económico, v. 37, n. 147, p. 353, 1997.

${ }^{99}$ BANCO MUNDIAL. Annual Reports (anos 1992 a 1995).

${ }^{100}$ STIGLITZ, Joseph. A globalização e seus malefícios: a promessa não-cumprida de benefícios globais. 4. ed. São Paulo: Futura, 2003. p. 173-207; CHOSSUDOVSKY, Michel. A globalização da pobreza: impactos das reformas do FMI e do Banco Mundial. 2. reimpr. São Paulo: Moderna, 1999. p. 214-30; GRAY, John. Falso amanhecer: os equívocos do capitalismo global. Rio de Janeiro: Record, 1999. p. 175-216.

${ }^{101}$ BANCO MUNDIAL. World Development Report. Washington, DC, 1990.

${ }^{102}$ BABB, Sarah, op. cit., p. 165-166.
} 
A segunda coordenada estratégica consistiu na redefinição do papel do Estado na economia. O RDM 1991 prescreveu o enfoque "amigável com o mercado" (market-friendly approach), o qual pregava que ao Estado cabia apoiar, fortalecer e complementar o mercado em regime de livre concorrência. Ou seja, já não se tratava simplesmente de condenar qualquer "intervenção estatal" na economia como algo indesejável em si, mas sim de reconhecer o âmbito de ação legítimo do Estado. Qual? O que se "harmoniza" com o mercado e permite a maximização da concorrência entre os agentes econômicos. ${ }^{103}$ A dicotomia Estado versus mercado, típica do enfoque hipermercadista dos anos 1980, começava a dar lugar a uma visão mais complementar. Nesse sentido, a garantia de um "ambiente" favorável ao capital demandaria do Estado as seguintes funçóes: manter a estabilidade macroeconômica (mediante o insulamento da política econômica), garantir a ordem pública, investir em "capital humano" (educação primária e saúde básica), fornecer infraestrutura, proteger o meio ambiente, controlar a natalidade e gerir a previdência social. Como empresário, o Estado estaria irremediavelmente condenado ao fracasso.

A terceira coordenada estratégica consistiu na incorporação do "meio ambiente" ao programa político dominante. Com efeito, no início dos anos 1990, a fragilidade do flanco ambiental era considerada pela alta administraçáo do banco como o problema mais grave de "relaçôes públicas" da entidade. ${ }^{104}$ Àquela altura, tornara-se politicamente insustentável desdenhar os impactos ambientais e a tragédia social provocados por inúmeros projetos financiados pela instituiçâao. ${ }^{105}$ Como resposta, o banco começou a falar em "administração ambiental". A proximidade da Conferência das Naçóes Unidas para o Meio Ambiente e o Desenvolvimento, marcada para junho de 1992, acentuou a urgência de se demarcar uma posição de liderança na arena internacional.

Publicado um mês antes da conferência, o RDM 1992 tinha o propósito de compatibilizar a consigna do "desenvolvimento sustentável" com a liberalização econômica ${ }^{106}$. O relatório afirmava a reciprocidade entre crescimento econômico e preservação ambiental, na medida em que somente com o crescimento da economia seria possível não apenas arcar com os custos da proteção ambiental, mas também diminuir a pressão social sobre a natureza. A idealização da tecnologia que dava suporte a essa visão projetava um cenário irreal em que todos ganhariam, desde que os governos adotassem políticas orientadas ao mercado, pois só assim poderia a atividade econômica crescer com eficiência máxima no uso dos recursos.

${ }^{103}$ BANCO MUNDIAL. Informe sobre el Desarrollo Mundial. Washington, DC, 1991. p. 6.

${ }^{104}$ WADE, Robert. Greening the Bank: the struggle over the environment, 1970-1995. In: KAPUR, Devesh et al. (Eds.). The World Bank: its First Half Century — Perspectives. Washington, DC: Brookings Institution Press, 1997a. v. 2, p. 672.

${ }^{105} \mathrm{RICH}$, Bruce. Mortgaging the Earth: the World Bank, Environmental Impoverishment, and the Crisis of Development. Boston: Beacon Press, 1994; GEORGE, Susan; SABELLI, Fabrizio, op. cit.; CAUFIELD, Catherine, op. cit.

${ }^{106}$ BANCO MUNDIAL. World Development Report. Washington, DC, 1992. 
Em resumo, no início da década de 1990 o banco respondeu às críticas ambientalistas se esverdeando. Esse processo, longe de pôr em xeque o programa neoliberal, constituiu-se numa nova frente de atuação centrada na promoção de um regime internacional de regras e práticas institucionais que viabilizasse a mercantilização de recursos naturais. ${ }^{107}$

A quarta coordenada definida pelo banco funcionou como elemento de ligação entre todas as demais e consistiu na entronização da ideia de governança (governance). O termo foi introduzido no vocabulário do banco em 1989 por um relatório sobre a implementação do ajuste estrutural na África subsaariana. ${ }^{108}$ De acordo com o informe, o crescimento do investimento privado e os programas de ajustamento não haviam dado os resultados esperados na região em termos de eficiência e redução da pobreza devido à "má" governança entre os atores que operavam no plano doméstico. Desde entáo, essa se tornou a resposta padrão do banco aos críticos do ajuste.

Em 1992, o banco publicou o primeiro informe específico sobre o tema, centrado na mensagem de que a engenharia institucional e a qualidade da gestão pública eram cruciais para a execução do ajuste. Governança foi definida como a "maneira pela qual o poder é exercido na administração de recursos sociais e econômicos de um país para o desenvolvimento". ${ }^{109}$ Para a criação de um ambiente propício à liberdade do capital, já não bastavam apenas políticas econômicas "sólidas", sendo necessário também adequar os marcos legais e melhorar a qualidade da administração pública e da ação governamental como um todo. A tese de que a eficácia da gestão pública depende da articulação entre Estado e sociedade civil foi posta em primeiro plano. Todavia, sociedade civil foi tomada como sinônimo apenas de associaçóes voluntárias e ONGs.

O elogio ao papel de ONGs para a boa governança se materializava nas operaçóes do próprio banco. Com efeito, a entrada de ONGs no ciclo de projetos da instituição havia crescido continuamente durante os anos 1980, chegando em 1994 a quase metade dos seus projetos. ${ }^{110} \mathrm{Em}$ larga medida, esse processo resultava da permeabilidade crescente entre o campo das ONGs e a indústria internacional da ajuda e era alimentado pelo ajuste estrutural, que abria enorme espaço àquelas ONGs preparadas para desempenhar funçôes arrancadas dos Estados nas áreas social e ambiental. ${ }^{111}$ Para sobreviver e prosperar num mercado cada vez mais competitivo - o mercado internacional de consultorias e gestáo de projetos sociais —, ativistas se converteram em especialistas em leis e "práticas responsáveis", credenciando-se para negociar a captação de fundos em círculos políticos e empresariais cada vez mais globalizados. ${ }^{112}$

\footnotetext{
${ }^{107}$ WADE, Robert, op. cit., 1997a, p. 711; GOLDMAN, Michael, op. cit., p. 121-131.

${ }^{108}$ BANCO MUNDIAL. Sub-Saharan Africa: From Crisis to Sustainable Growth. Washington, DC, 1989.

${ }^{109}$ BANCO MUNDIAL. Governance and Development. Washington, DC: 1992. p. 1.

${ }^{110}$ COVEY, Jane. Critical cooperation? Influencing the World Bank through policy dialogue and operational cooperation. In: FOX, Jonathan; BROWN, David (Eds.). The Struggle for Accountability: the World Bank, NGOs and grassroots movements. Cambridge/Londres: MIT Press, 1998. p. 83.

${ }^{111}$ DAVIS, Mike, op. cit., p. 83-84; DEZALAY, Yves; GARTH, Bryant, op. cit., p. 288-300.

${ }^{112}$ GUILHOT, Nicolas, op. cit., p. 215-217.
} 
A imbricação de ONGs - em particular, aquelas sediadas nos principais países-membros - nas operaçóes do banco não foi um processo isento de contradiçóes. A cultura organizacional do banco o havia fechado por muito tempo a qualquer tipo de colaboraçáo com ONGs. Aos poucos, o banco estava se tornando uma organização mais aberta, com o efeito adicional de que a colaboração com ONGs, mesmo as mais críticas, podia limitar o âmbito das críticas, dado o seu enquadramento às regras do campo da ajuda ao desenvolvimento. ${ }^{113}$

A agenda da "boa governança" se tornou possível pelo uso crescente dos empréstimos de ajustamento estrutural, que deu ao banco instrumentos para reformar a infraestrutura institucional dos Estados clientes, e pela combinação do fim da Guerra Fria com a euforia da globalização financeira, que eliminou os constrangimentos políticos dos Estados Unidos e outros doadores em violar, na prática, a soberania nacional de países do Sul global. Assim, governança passou a ser o slogan geral que aglutinava as políticas, as técnicas e os saberes necessários para impulsionar e dirigir a mudança social dentro dos Estados sem o exercício de controle político direto. ${ }^{114}$ É emblemático, nesse sentido, que o discurso de representantes de países como EUA, Grã-Bretanha, Alemanha e França se tornasse idêntico ao mesmo tempo, em exaltação a tal agenda. ${ }^{15}$

Seguindo a pauta do ajuste macroeconômico e da boa governança, o Banco Mundial chegou ao aniversário de 50 anos de Bretton Woods numa situação ambígua. Por um lado, havia atingido o seu máximo histórico em termos de incidência geográfica, volume de empréstimos e autoridade intelectual, e sua atuação havia sido decisiva para alargar o espaço social de valorizaçáo do capital. Por outro lado, encontrava-se sob intenso fogo cruzado em meio a ásperas polêmicas sobre o presente e o futuro da instituição.

Três linhas de ataque se superpunham. A primeira vinha de ONGs americanas e europeias que denunciavam os impactos socioambientais provocados por projetos e programas de ajuste financiados pelo banco. Tais vozes estavam engajadas em duas grandes açôes: a campanha por transparência e accountability, mais moderada, e a campanha 50 years is enough, mais radical e heterogênea, que exigia o cancelamento da dívida externa dos países do Sul e entoava a palavra de ordem "reforma ou fecha" ( fix it or nix it).

A segunda linha advogava a revisão das funções do banco e do FMI frente à globalização financeira, propondo que a instituição deixasse de financiar o setor público e atuasse como "mobilizador de recursos" (privados e públicos, intelectuais e financeiros) para a expansão direta do setor privado. Tal proposta seguia no rastro da discussão sobre a perda de relevância política e econômica da ajuda externa, em função do fim da Guerra Fria e da globalização financeira. Dentro do establishment americano, um dos seus pivôs era a Comissão Bretton Woods,

${ }^{113}$ WILLIAMS, David; YOUNG, Tom. The world Bank and the liberal project. In: MOORE, David (Ed.). The World Bank: Development, Poverty, Hegemony. Scottsville: University of KwaZulu-Natal Press, 2007. p. 208; DEZALAY, Yves; GARTH, Bryant, op. cit., p. 282.

${ }_{114}$ WILLIAMS, David; YOUNG, Tom, op. cit., p. 216.

115 WILLIAMS, David. The World Bank and Social Transformation in International Politics. Londres: Routledge, 2008. p. 75-76; BABB, Sarah, op. cit., p. 158. 
presidida por Paul Volcker, ex-presidente do Federal Reserve. Criada em 1983, a Comissão era composta por membros dos partidos Democrata e Republicano, banqueiros de investimento e empresários envolvidos com projetos financiados pelo banco ao redor do mundo.

A terceira linha sustentava que os BMDs haviam se tornado irrelevantes enquanto fontes de financiamento, dada a discrepância abissal entre o volume das transaçóes diárias nos mercados de capitais e a carteira das fontes multilaterais de crédito. Desse ponto de vista, tais organizaçôes deveriam ser reduzidas ou mesmo dissolvidas, assim como todo o sistema de ajuda internacional ao desenvolvimento, em favor da liberalização radical dos mercados financeiros. Essa vertente estava nucleada no Cato Institute, na Heritage Fundation e no American Enterprise Institute, e agregava ultraliberais e críticos contumazes do multilateralismo.

No final de 1994, o México - a economia estrela da América Latina, segundo o banco e o FMI — entrou em colapso, precisamente quando se iniciava o Tratado Norte-Americano de Livre Comércio (Nafta). Em poucos meses o país afundou na maior recessão desde os anos de 1930. Rapidamente, Washington arregimentou um pacote inédito de socorro financeiro, do qual tomaram parte o Banco Mundial e do FMI. Pela primeira vez desde o fim da Guerra Fria, a euforia neoliberal sofria algum abalo. Para o complexo Washington-Wall Street, a resposta a tal situaçáo consistia em aumentar a intensidade do ajuste macroeconômico e iniciar um ciclo mais lento e tortuoso de reformas institucionais profundas. ${ }^{116} \mathrm{O}$ Banco Mundial seria o pivô da difusão dessa agenda nas décadas seguintes, por meio de condicionalidades nas suas operaçôes de empréstimo, assistência técnica a governos nacionais e subnacionais e extensa produção autorizada de guias de políticas. ${ }^{117}$

\section{Conclusão}

O Banco Mundial foi forjado como parte da infraestrutura de poder global dos EUA. Os atributos de poder que gradualmente deram ao banco uma condiçáo ímpar entre as

\footnotetext{
${ }^{116}$ Cf. BURKI, Shahid Javed; EDWARDS, Sebastián. Latin America after Mexico: Quickening the Pace. Washington, DC: The World Bank, 1996; Dismantling the Populist State: the Unfinished Revolution in Latin America and the Caribbean. Washington, DC: The World Bank, 1996; BURKI, Shahid J.; PERRY, Guillermo. The Long March: a Reform Agenda for Latin America and the Caribbean in the Next Decade. Washington, DC: The World Bank, 1997; NAÍM, Moisés. Transição para o regime de mercado na América Latina: dos choques macroeconômicos à terapia institucional. In: LANGONI, Carlos (Org.). A Nova América Latina. Rio de Janeiro: FGV, 1996. p. 211-263.

117 Cf. BANCO MUNDIAL. Governance and Development. Washington, DC: Oxford University Press, 1992; World Development Report: The State in a Changing World. Washington, DC;

World Development Report: Building Institutions for Market. Washington, DC; BURKI, Shahid J.; PERRY, Guillermo. Más allá del Consenso de Washington: la hora de la reforma institucional. Washington, DC: Banco Mundial, 1998; CRAIG, David; PORTER, Doug. Development Beyond Neoliberalism? Governance, Poverty Reduction and Political Economy. Nova York: Routledge, 2006; WILLIAMS, David. The World Bank and Social Transformation in International Politics. Londres/Nova York: Routledge, 2008.
} 
demais organizaçôes internacionais construídas no pós-guerra decorreram de contingências históricas, decisóes institucionais e, fundamentalmente, da supremacia americana. Do ponto de vista político e financeiro, os EUA sempre foram o maior acionista e o membro mais influente da instituição. As relaçôes com os EUA foram decisivas para o crescimento e a configuração geral das políticas e práticas institucionais do banco. Em troca, os EUA se beneficiaram largamente da ação da entidade em termos econômicos e políticos, mais do que qualquer outro acionista, tanto no curto como no longo prazos.

Por sua vez, a política americana para o banco sempre foi objeto de disputa e barganha entre interesses econômicos e políticos diversos quanto ao papel da cooperaçáo multilateral e da ajuda ao desenvolvimento. Dessa disputa emergiram dois vetores cujo balanço variou ao longo do período examinado. Por um lado, os EUA protagonizaram a construçáo da indústria internacional da ajuda e do Banco Mundial como instrumentos para a promoção de uma economia internacional livre e aberta ao capital no pós-guerra, apoiando a cooperação multilateral como meio efetivo para alavancar e alocar recursos para essa finalidade e, assim, desonerar a carga dos EUA com a ajuda econômica bilateral. Por outro lado, os EUA também buscaram instrumentalizar diretamente as organizaçôes internacionais, incluindo o Banco Mundial, para fins imediatos da sua política externa, contrariando a pregação sobre o multilateralismo.

Com o passar do tempo, a disputa passou a envolver um número cada vez maior de atores políticos e econômicos. A partir do final dos anos 1960, a ingerência crescente do Congresso sobre a política externa dos EUA chegou ao Banco Mundial, abrindo aos poucos pontos de entrada durante a década seguinte para que interesses variados influenciassem as provisões americanas para a instituição. Até então, a política de Washington para o banco havia sido definida basicamente pelo jogo de poder discreto e por detrás das cortinas entre o Tesouro e o Departamento de Estado. Durante os anos 1980, o ativismo de parlamentares criou oportunidades para que grupos políticos e ONGs agissem por dentro do Legislativo, com o objetivo de pautar as açóes do banco em matéria social e ambiental. Desde então, o Congresso se tornou alvo de lobbies e campanhas públicas voltadas para influenciar a política dos EUA para o banco. Isso transformou o Congresso americano no único parlamento cujos trâmites de fato têm peso sobre as pautas e a forma de atuação do banco, o que, paradoxalmente, reforça a gravitação dos EUA sobre a organização.

O Banco Mundial sempre atuou como mais do que um mero agente financeiro. Afinal, junto com o dinheiro vinham ideias e prescriçóes para os governos dos Estados clientes em matéria de política econômica e desenvolvimento. Com efeito, o banco continuamente explorou a sinergia entre crédito, prescriçóes políticas e saber econômico para ampliar a sua influência e institucionalizar a sua pauta, mediante a combinação de coerção (constrangimento junto a outros financiadores, bloqueio de empréstimos e, com mais frequência, condicionalidades) e persuasão (assistência técnica a governos e crescente e autorizada produção intelectual). 
Em 1994, o Banco Mundial havia se tornado uma organização imensa e de enorme complexidade, muito diferente daquela acordada em 1944. Cinco décadas crescendo e desempenhando mais funçôes mediante mudanças incrementais sucessivas, o banco operava muito além da sua área original de competência, abarcando as mais variadas dimensões do desenvolvimento. Esse processo foi apoiado por Washington e seus principais aliados durante a Guerra Fria, e sobreviveu a ela como meio de difusão da liberalização econômica a todas as sociedades ao Sul e ao Leste. Por outro lado, o estiramento institucional do banco abriu pontos de entrada para que, de forma crescente e muitas vezes contraditória, atores diversos tivessem incidência nas políticas e prioridades da instituição.

Seguindo a pauta do ajuste macroeconômico e da boa governança, o Banco Mundial chegou ao seu aniversário de 50 anos numa situação paradoxal. Por um lado, havia atingido o seu máximo histórico em termos de escala geográfica, volume de empréstimos e autoridade intelectual, e sua atuação contribuíra decisivamente para criar uma economia mais livre e aberta ao capital. Por outro lado, encontrava-se sob críticas oriundas de pontos muito diversos do espectro político. Com efeito, o fim da Guerra Fria, a desregulação financeira e a magnitude da concentração bancária no mundo puseram em questão a sua relevância como ator econômico. Para o banco, embora o dinheiro tivesse funcionado como alavanca para difundir ideias e prescriçôes, em clave anglo-saxônica, sobre o desenvolvimento capitalista, o crédito sempre foi fundamental e era isso que o distinguia das demais organizaçóes multilaterais. Esse debate veio à tona no início dos anos 1990 e desde então não saiu mais da pauta. Por outro lado, o banco era pressionado também para que mudasse o seu programa e suas práticas, haja vista o enorme passivo social e ambiental, gerado ou agravado pela sua atuação, e o seu histórico de opacidade e baixíssimo grau de accountability. Tais questionamentos também prosseguem desde entâo.

\section{Referências bibliográficas}

AGLIETTA, Michel; MOATTI, Sandra. El FMI: del orden monetario a los desórdenes financieros. Madri: Akal, 2002.

ALACEVICH, Michele. The Political Economy of the World Bank: the Early Years. Palo Alto/ Washington, DC: Stanford University Press/The World Bank, 2009.

ARANTES, Pedro Fiori. O ajuste urbano: as políticas do Banco Mundial e do BID para as cidades latino-americanas. Dissertação (Mestrado em Arquitetura e Urbanismo) — Programa de Pós-graduação em Arquitetura e Urbanismo, Universidade de São Paulo, 2004.

ASCHER, William. The World Bank and U.S. control. In: KARNS, Margaret; MINGST, Karen (Eds.). The United States and Multilateral Institutions: Patterns of Changing Instrumentality and Influence. Boston: Unwin Hyman, 1990. 
ASSMANN, Hugo. El "progresismo conservador" del Banco Mundial. In: ASSMANN, Hugo (Ed.). Banco Mundial: un caso de "progresismo conservador". San José: DPI, 1980. AYRES, Robert. Banking on the Poor: the World Bank and World Poverty. Londres: MIT Press, 1983.

BABB, Sarah. Behind the Development Banks: Washington Politics, World Poverty, and the Wealthy of Nations. Chicago: The University of Chicago Press, 2009.

. The Washington Consensus as transnational policy paradigm: Its origins, trajectory and likely successor. Review of International Political Economy, v. 20, n. 2, p. 268-297, 2013. BANCO MUNDIAL. Annual Reports (anos 1992 a 1995).

. Governance and Development. Washington, DC: Oxford University Press, 1992. . Informe sobre el Desarrollo Mundial. Washington, DC, 1991.

. Sub-Saharan Africa: From Crisis to Sustainable Growth. Washington, DC, 1989.

. World Development Report. Washington, DC, 1990.

. World Development Report. Washington, DC, 1992.

. World Development Report. Building Institutions for Market. Washington, DC, 2002.

. World Development Report: The State in a Changing World. Washington, DC, 1997. BANDEIRA, Luiz Alberto Moniz. Formação do império americano: da guerra contra a Espanha à guerra no Iraque. 2. ed. Rio de Janeiro: Civilização Brasileira, 2006.

BLOCK, Fred. Los orígenes del desorden económico internacional. México, DF: Fondo de Cultura Económica, 1989.

BRENNER, Robert. O boom e a bolha: os Estados Unidos na economia mundial. Rio de Janeiro: Record, 2003.

BROWN, Michael Barrat. Africa's Choices after Thirty Years of the World Bank. Boulder: Westview Press, 1995.

BURKI, Shahid Javed; PERRY, Guillermo. Más allá del Consenso de Washington: la hora de la reforma institucional. Washington, DC: Banco Mundial, 1998.

BURKI, Shahid Javed.; PERRY, Guillermo. The Long March: a Reform Agenda for Latin America and the Caribbean in the Next Decade. Washington, DC: The World Bank, 1997. BURKI, Shahid Javed; EDWARDS, Sebastián. Latin America after Mexico: Quickening the Pace. Washington, DC: The World Bank, 1996.

. Dismantling the Populist State: the Unfinished Revolution in Latin America and the Caribbean. Washington, DC: The World Bank, 1996.

CAUFIELD, Catherine. Masters of Illusion: the World Bank and the Poverty of Nations. Nova York: Henry Holt, 1996. 
COVEY, Jane. Critical cooperation? Influencing the World Bank through policy dialogue and operational cooperation. In: FOX, Jonathan; BROWN, David (Ed.). The Struggle for Accountability: the World Bank, NGOs and grassroots movements. Cambridge/Londres: MIT Press, 1998.

CRAIG, David; PORTER, Doug. Development Beyond Neoliberalism? Governance, Poverty Reduction and Political Economy. Nova York: Routledge, 2006.

CHENERY, Hollis. Redistribution with Growth. Londres: Oxford University Press, 1974. CHOSSUDOVSKY, Michel. A globalizaçâo da pobreza: impactos das reformas do FMI e do Banco Mundial. 2. reimpr. São Paulo: Moderna, 1999.

DAVIS, Mike. Planeta Favela. São Paulo: Boitempo, 2006.

DEZALAY, Yves; GARTH, Bryant. La internacionalización de las luchas por el poder. México, DF: Instituto de Investigaciones Jurídicas/Universidad Nacional Autónoma de México, 2005.

EICHENGREEN, Barry. A globalização do capital: uma história do sistema monetário internacional. São Paulo: Editora 34, 2000.

ESCOBAR, Arturo. La invención del Tercer Mundo: construcción y deconstrucción del desarrollo. Bogotá: Editorial Norma, 1996.

FEDER, Ernest. La pequena revolución verde de McNamara. Comercio Exterior, v. 26, n. 7, p. 793, 1976.

FINNEMORE, Martha. Redefining development at the World Bank. In: COOPER, Frederick; PACKARD, Randall (Eds.). International Development and the Social Sciences. Berkeley: University of California Press, 1997

FIORI, José Luís. O poder global dos Estados Unidos: formação, expansão e limites. In: . (Org.). O poder americano. Petrópolis: Vozes, 2004.

FONTANA, Josep. Por el bien del imperio: una historia del mundo desde 1945. Barcelona: Pasado \& Presente, 2011.

GARCÉS, Joan. Soberanos e intervenidos: estrategias globales, americanos y españoles. 3. ed. Madri: Siglo XXI, 2008.

GARDNER, Richard. La diplomacia del dólar y la esterlina. Barcelona: Galaxia Gutenberg/ Círculo de Lectores, 1994.

GAVIN, Michael; RODRIK, Dani. The World Bank in historical perspective. American Economic Review, v. 85, n. 2, p. 333, maio 1995.

GEORGE, Susan. O mercado da fome. Rio de Janeiro: Paz e Terra, 1978.

GEORGE, Susan; SABELLI, Fabrizio. La religión del crédito: el Banco Mundial y su imperio secular. 2. ed. Barcelona: Intermón. 1996. 
GOLDMAN, Michael. Imperial Nature: the World Bank and Struggles for Social Justice in the Age of Globalization. New Haven: Yale University Press, 2005.

GOWAN, Peter. A roleta global: uma aposta faustiana de Washington para a dominação do mundo. Rio de Janeiro: Record, 2003.

GRAY, John. Falso amanhecer: os equívocos do capitalismo global. Rio de Janeiro: Record, 1999.

GUILHOT, Nicolas. The Democracy Makers: Human Rights and the Politics of Global Order. Nova York: Columbia University Press, 2005.

GWIN, Catherine. U.S. relations with the World Bank, 1945-1992. In: KAPUR, Devesh et al. (Eds.). The World Bank: its First Half Century. Perspectives. Washington, DC: Brookings Institution Press, [S.d.]. v. 2.

HELLEINER, Eric. States and the Reemergence of Global Finance: from Bretton Woods to the 1990s. Ithaca: Cornell University Press, 1994.

HUNTINGTON, Samuel. A ordem politica nas sociedades em mudança. São Paulo/Rio de Janeiro: USP/Forense Universitária, 1975.

KANBUR, Ravi; VINES, David. The World Bank and poverty reduction: past, present and future. In: GILBERT, Christopher; VINES, David (Eds.). The World Bank: Structure and Policies. Cambridge: Cambridge University Press, 2000

KAPUR, Devesh et al. The World Bank: its First Half Century. History. Washington, DC: Brookings Institution Press, 1997. v. 1.

KIRK, Jason. India and the World Bank. Londres: Anthem, 2010.

KOFAS, Jon. Independence from America: Global Integration and Inequality. Burlington: Ashgate, 2005.

. The politics of austerity: the IMF and U.S. foreign policy in Bolivia, 1956-1964, The Journal of Developing Areas, v. 29, n. 2, p. 213-35, jan. 1995.

. The Sword of Damocles: U.S. Financial Hegemony in Colombia and Chile, 19501970. Westport: Praeger, 2002.

KOLKO, Gabriel. The Politics of War: the World and United States Foreign Policy, 1943-45. Nova York: Pantheon, 1990.

KRIGE, John. American Hegemony and the Postwar Reconstruction of Science in Europe. Cambridge/Londres: MIT Press, 2006.

LANCASTER, Carol. Foreign Aid: Diplomacy, Development, Domestic Politics. Chicago: The University of Chicago Press, 2007.

LAPPÉ, Frances M.; COLLINS, Joseph. Comer és primero: más allá del mito de la escasez. México, DF: Siglo XXI, 1982. 
LATHAM, Michael. Modernization as Ideology: American Social Science and "Nation Building" in the Kennedy Era. Chapel Hill/Londres: The University of Carolina Press, 2000.

LICHTENSZTEJN, Samuel; BAER, Mônica. Fundo Monetário Internacional e Banco Mundial: estratégias e políticas do poder financeiro. São Paulo: Brasiliense, 1987.

MASON, Edward; ASHER, Robert. The World Bank since Bretton Woods. Washington, DC: The Brookings Institution, 1973.

McNAMARA, Robert. A essência da segurança. São Paulo: Ibrasa, 1968.

. A imposição do desenvolvimento. In: McNAMARA, Robert. Cem países, dois bilhóes de seres: a dimensão do desenvolvimento. Rio de Janeiro: Fundação Getulio Vargas, 1974.

NAÍM, Moisés. Transição para o regime de mercado na América Latina: dos choques macroeconômicos à terapia institucional. In: LANGONI, Carlos (Org.). A Nova América Latina. Rio de Janeiro: FGV, 1996.

OLIVER, Robert. George Woods and the World Bank. Boulder: Lynne Rienner, 1995.

PAULY, Louis. Who Elected the Bankers? Surveillance and Control in the World Economy. Ithaca: Cornell University Press, 1997.

PAYER, Cheryl. The Debt Trap: the International Monetary Fund and the Third World. Nova York: Monthly Review Press, 1974.

. The World Bank: a Critical Analysis. Nova York: Monthly Review Press, 1982.

PERKINS, John H. Geopolitics and the Green Revolution: Wheat, Genes, and the Cold War. Nova York: Oxford University Press, 1997.

RICH, Bruce. Mortgaging the Earth: the World Bank, Environmental Impoverishment, and the Crisis of Development. Boston: Beacon Press, 1994.

ROBIN, Ron. The Making of the Cold War Enemy: Culture and Politics in the MilitaryIntellectual Complex. Princeton: Princeton University Press, 2001.

SANAHUJA, José. Altruismo, mercado y poder: el Banco Mundial y la lucha contra la pobreza. Barcelona: Intermón Oxfam, 2001.

SCHOULTZ, Lars. Politics, Economics, and U.S. Participation in Multilateral Development Banks. International Organization, v. 36, 1982.

SHIVA, Vandana. The Violence of Green Revolution. Londres: Zed Books, 1991.

SOGGE, David. Dar y tomar: ¿qué sucede con la ayuda internacional? Barcelona: Icaria Editorial, 2002.

STERN, Nicholas; FERREIRA, Francisco. The World Bank as 'intellectual actor'. In: KAPUR, Devesh et al. (Eds.). The World Bank: its First Half Century — Perspectives. Washington, DC: Brookings Institution Press, 1997. v. 2. 
STIGLITZ, Joseph. A globalização e seus malefícios: a promessa não-cumprida de benefícios globais. 4. ed. São Paulo: Futura, 2003.

STRANGE, Susan. Dinero loco: el descontrol del sistema financiero global. Buenos Aires: Paidós, 1999.

STREETEN, Paul et al. Lo primero es lo primero. Madri: Tecnos/Banco Mundial, 1986.

TABB, William. Economic Governance in the Age of Globalization. Nova York: Columbia University Press, 2004.

TAVARES, Maria da Conceição. A retomada da hegemonia norte-americana. In:

FIORI, José Luís (Org.) Poder e dinheiro: uma economia política da globalização. Petrópolis: Vozes, 1997.

TOUSSAINT, Eric. Banco Mundial: el golpe de Estado permanente. Madri: El Viejo Topo, 2006.

WADE, Robert. Greening the Bank: the struggle over the environment, 1970-1995. In: KAPUR, Devesh et al. (Eds.). The World Bank: its First Half Century - Perspectives. Washington, DC: Brookings Institution Press, 1997a. v. 2.

WADE, Robert. Japón, el Banco Mundial y el arte del mantenimiento del paradigma: el Milagro del Este Asiático en perspectiva política. Desarrollo Económico, v. 37, n. 147, p. 353, 1997.

WILLIAMS, David. The World Bank and Social Transformation in International Politics. Londres: Routledge, 2008.

WILLIAMS, David; YOUNG, Tom. The world Bank and the liberal project. In: MOORE, David (Ed.). The World Bank: Development, Poverty, Hegemony. Scottsville: University of KwaZulu-Natal Press, 2007.

WILLIAMSON, John. What Washington means by policy reform. In: (Org.). $L a-$ tin American Adjustment: How Much has Happened. Washington, DC: IIE, 1990. p. 5-20. WOODS, Ngaire. The Globalizers: the IMF, the World Bank and their Borrowers. Ithaca: Cornell University Press, 2006. 